\title{
Traditional Houses and Projective Geometry: Building Numbers and Projective Coordinates
}

\author{
Wen-Haw Chen $\mathbb{D}^{1}$ and Ja'faruddin $\mathbb{D i D}^{1,2}$ \\ ${ }^{1}$ Department of Applied Mathematics, Tunghai University, Taichung 407224, Taiwan \\ ${ }^{2}$ Department of Mathematics, Universitas Negeri Makassar, Makassar 90221, Indonesia \\ Correspondence should be addressed to Ja'faruddin; jafaruddin@unm.ac.id
}

Received 6 March 2021; Accepted 27 July 2021; Published 1 September 2021

Academic Editor: Md Sazzad Hossien Chowdhury

Copyright (c) 2021 Wen-Haw Chen and Ja'faruddin. This is an open access article distributed under the Creative Commons Attribution License, which permits unrestricted use, distribution, and reproduction in any medium, provided the original work is properly cited.

\begin{abstract}
The natural mathematical abilities of humans have advanced civilizations. These abilities have been demonstrated in cultural heritage, especially traditional houses, which display evidence of an intuitive mathematics ability. Tribes around the world have built traditional houses with unique styles. The present study involved the collection of data from documentation, observation, and interview. The observations of several traditional buildings in Indonesia were based on camera images, aerial camera images, and documentation techniques. We first analyzed the images of some sample of the traditional houses in Indonesia using projective geometry and simple house theory and then formulated the definitions of building numbers and projective coordinates. The sample of the traditional houses is divided into two categories which are stilt houses and nonstilt house. The present article presents 7 types of simple houses, 21 building numbers, and 9 projective coordinates.
\end{abstract}

\section{Introduction}

Mathematics has played an essential role in human life for thousands of years. Notable figures in many civilizations used mathematics to solve daily life problems. Some river civilizations, such as those in ancient Egypt and India, made exceptional achievements in mathematics. These achievements in mathematics were expressed in their buildings and recorded in writing [1].

Although some of these civilizations, such as those in ancient Maya [2,3] and ancient Egypt, have disappeared, their buildings remain and can be studied by scientists (Figure 1). These buildings suggest that ancient people constructed their buildings using their mathematical abilities. An ancient Egyptian papyrus (dated 1850 BC), called the Rhind Mathematical Papyrus (Figure 1(a)), revealed the geometrical knowledge of the Egyptians [4].

The shapes of the buildings resemble geometrical shapes, such as triangles, rectangles, and pyramids. For example, the ancient Egyptian pyramids of Giza (Figure 1(c)) have mathematical proportions either by accident or by design [6].

Scientists and mathematicians mainly focus on the mathematics of famous buildings of great ancient civilizations because buildings provide a massive information base to identify mathematical ideas. Mathematics concepts can also be traced from beautiful and monumental buildings. The types of mathematical ability required to construct buildings can generally be determined, especially regarding the required geometrical knowledge. However, local buildings, especially traditional houses, in small civilizations around the world can provide unique information regarding "natural mathematical ability." The villages built by the people of certain tribes are still standing. These traditional houses have unique shapes and reflect the intelligence of the people.

The achievements would not be possible without intuitive mathematics ideas because, for example, an ability to 


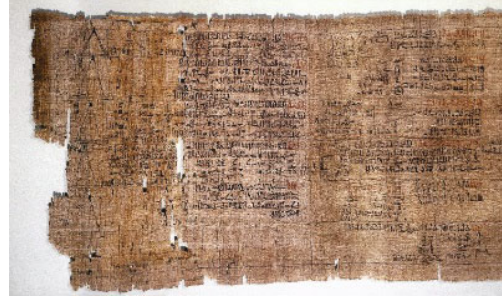

(a)

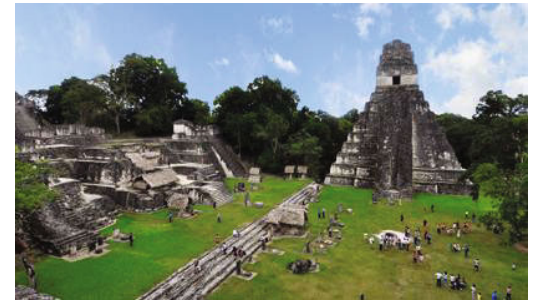

(b)

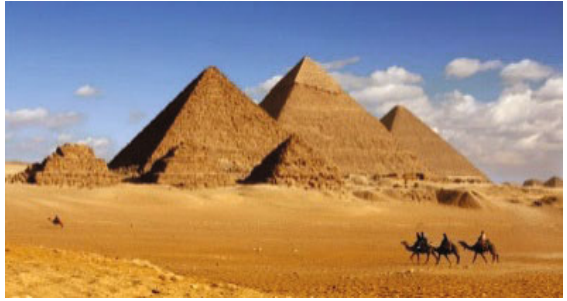

(c)

Figure 1: (a) The Rhind Mathematical Papyrus [5], (b) Aztec Maya [1], and (c) Pyramid in Egypt [6].

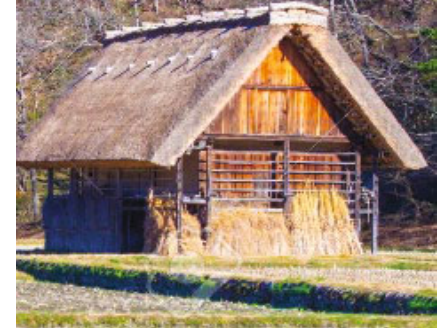

(a)

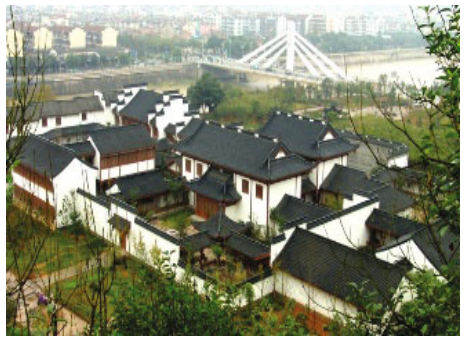

(c)

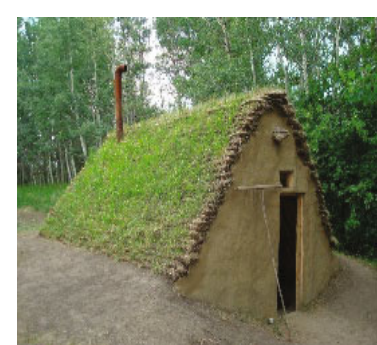

(b)

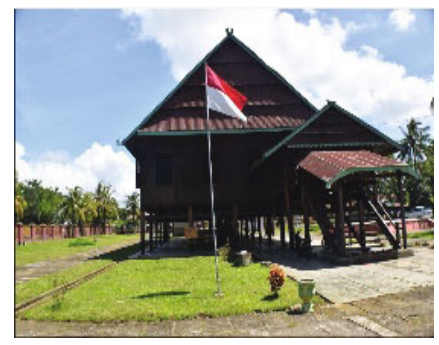

(d)

Figure 2: (a) Gassho Zukuri style, Japan [7]; (b) the Burdei, North America [8]; (c) the Siheyuan, China [9]; (d) Bola Soba, Indonesia [10].

measure the area and volume of buildings is required to make houses horizontally balanced. The ability to predict the relative position of a house with its foundation using knowledge regarding the perpendicular distance between two planes is required.

Furthermore, the model of some traditional houses is similar to that of other tribes in different areas, countries, and even continents. For example, Figures 2 and 3 illustrate the similarity between traditional houses around the world. Some tribes built traditional houses in which the roof forms a triangular prism [7-13]. These forms suggest that different local people had similar ideas when designing buildings and had similar geometrical concepts.

An examination of traditional house shapes allows an interpretation of intuitive mathematics ability in house expression. The concept of projective geometry could thus help us formulate and codify traditional houses. Chen and Ja'faruddin [10] defined traditional houses in some countries as simple houses that are build based on the theories of affine geometry and projective geometry. Affine geometry and projective geometry are mathematical interpretations of reality from the human eye perspective [14].
Form affine and projective geometry perspectives, buildings, and tools in human life are objects for learning and analyzing. Affine and projective geometry are the foundation of the new concept of building numbers and projective coordinates [10].

The concepts of building numbers and projective coordinates are established in this paper to classify traditional houses from Indonesia and other countries and explore their similarities. Furthermore, traditional houses worldwide were categorized as different types of simple houses.

This article contributes to mathematics education worldwide by introducing projective geometry and its relationship with cultures to high school students. Projective geometry differs from Euclidean geometry because it explains how the human eye perceives the real world. Numerous examples of projective geometry can be identified in a student's surroundings, and they can thus make simple interpretations of their view of traditional buildings from a projective geometry perspective.

This research encourages students to learn mathematical concepts from traditional houses. House theory can 


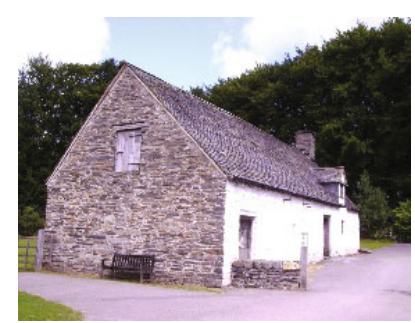

(a)

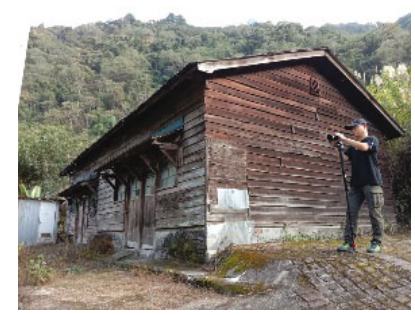

(c)

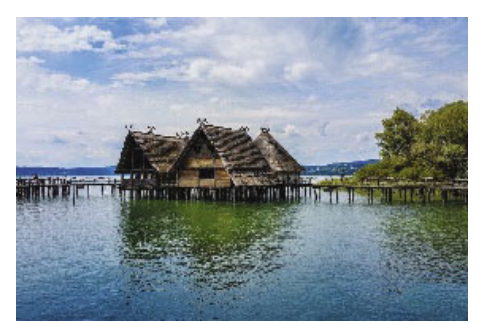

(b)

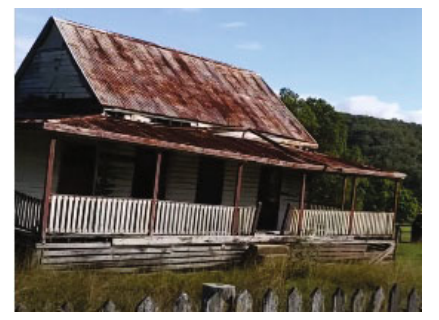

(d)

Figure 3: (a) The Dartmoor longhouse: Europe [11]; (b) stilt houses: Asia; (c) Central Taiwan; (d) Australia [12].

provide information regarding the mathematics surrounding them. Understanding the shape of one building can stimulate students' mathematics application in their daily lives. Students can classify traditional buildings and learn to use mathematics projection. They will thus realize that what they see is projective; this idea is an excellent introduction to the branch of mathematics that addresses human eye perspectives.

\section{Ethnomathematics}

Ethnomathematics was born as a counter to western mathematics. Western mathematics has eliminated local mathematics. Proponents of ethnomathematics attempt to reduce the domination of western mathematics, which is closely related to politics, stratified domination, ideology, and religion [15]. Since 1976, ethnomathematical studies have been conducted for almost every basic concept of mathematics, from algebra to geometry [15-19].

Ethnomathematics is the study of how people around the world use mathematics in everyday life. It involves investigating how various cultures in tribes mathematize their problems to identify the best solution for daily activities. Traditional mathematical concepts may differ from western mathematical concepts because they are highly related to the environment, methods of reasoning and inference, cultural traditions, myths, codes, symbols, and religions. Ethnomathematics is broader than the traditional concepts of mathematics, ethnicity, and multiculturalism. Ethnomathematics is a research area that incorporates philosophy, linguistics, pedagogy, anthropology, and history and has pedagogical implications in understanding different sociocultural environments [16].

Ethnomathematics emphasizes awareness of the various methods of performing and understanding mathematics depending on cultural values, traditional ideas and notions, and ethnic environmental contexts [16]. D'Ambrosio [20] defined ethnomathematics as referring to ethno and mathema where ethno is related to sociocultural contexts (e.g., language, jargon, code of behavior, myths, and symbols); mathema is defined as knowing, understanding, explaining, and performing activities to cipher, measure, classify, order, infer, and model; finally, the suffix tics has the same root as art and technique.

Some studies have investigated ethnomathematics in geometry concepts. Zang and Zang [19] reported that most African people in the Sahara and Mozambican peasantry built their traditional houses with circular structures or rectangular bases. The Mozambican peasantry constructed their house base as a rectangle without constructing the right angles one by one.

Sagdic [21] regarded architecture as having a symmetrical operation. The operation is highly related to isometric transformation, such as translation, rotation, reflection, and composition. Traditional Balinese houses and Borobudur Temple in Central Java, Indonesia, reflect these concepts. Balinese people built their houses using concepts of similarity, shift, and reflection [22]. Borobudur Temples have a fractal dimension, with 2- and 3-dimensional symmetrical conic or bell-shaped constructions [18].

\section{Projective Geometry}

In projective geometry, projective transformations explain how an eye perceives the real world and explain how artists can achieve realism in their works. A projective transformation preserves collinearity and incidence [14]. A projective transformation is a function $t: \mathbb{R} P^{2} \longrightarrow \mathbb{R} P^{2}$ of the form $t$ $:[x] \longrightarrow[A x]$, where $\mathbb{R} P^{2}$ is the real projective space and $A$ is an invertible $3 \times 3$ matrix. $A$ is defined as a matrix associated with $t$. 

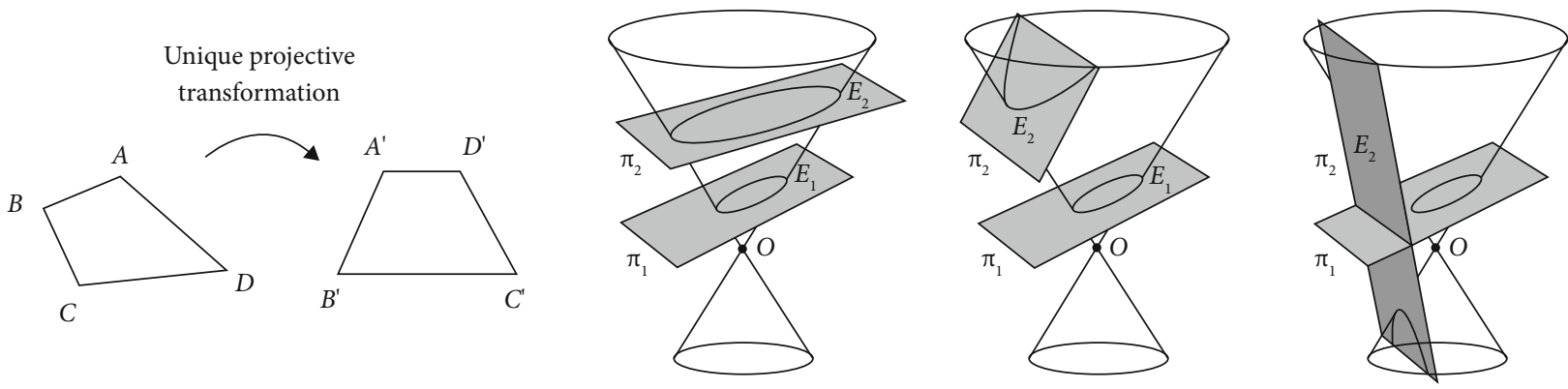

Figure 4: Projective transformation [14].
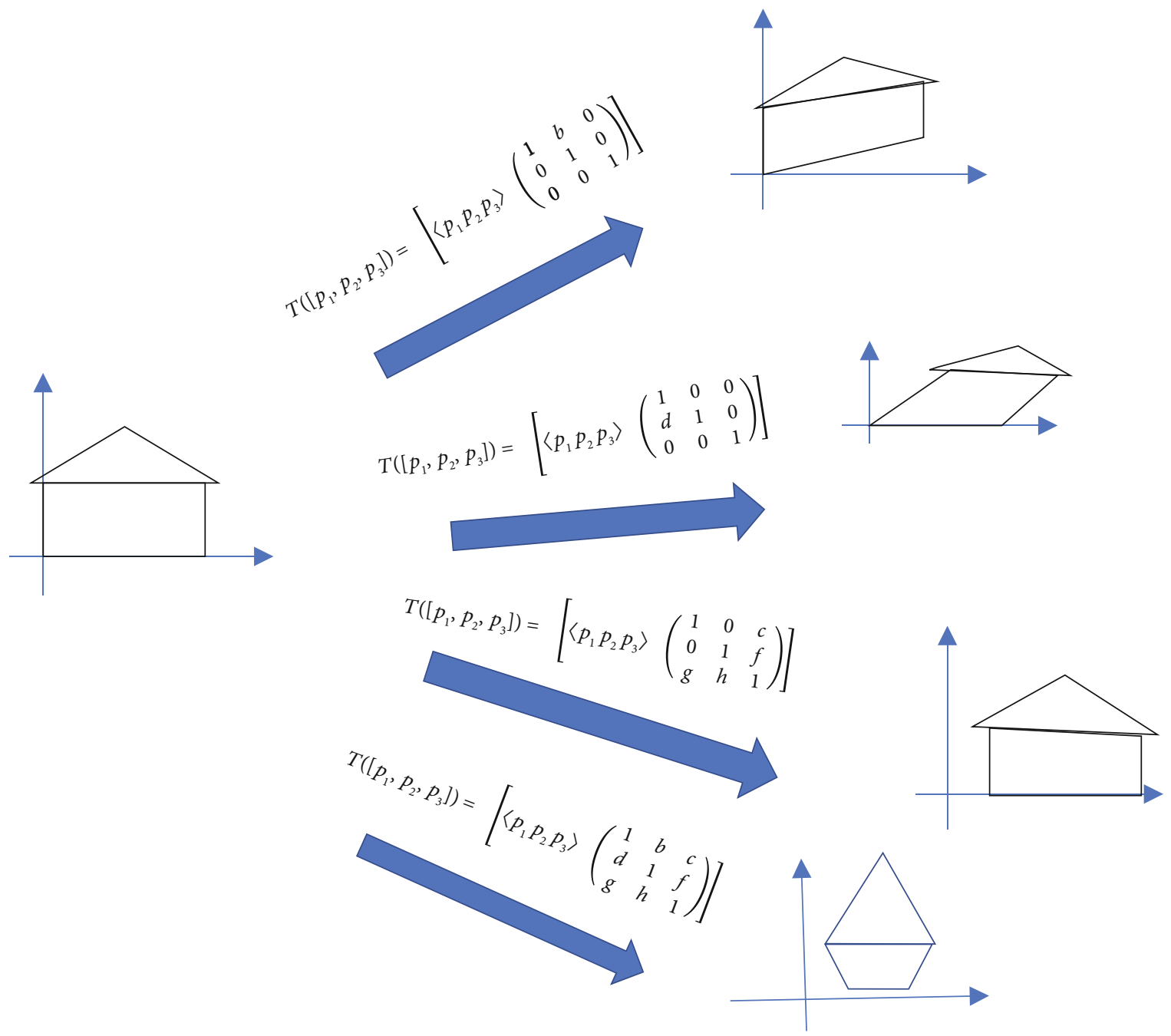

FiguRE 5: Matrix projective transformations.

The fundamental theorem of projective geometry is as follows:

Let $A B C D$ and $A^{\prime} B^{\prime} C^{\prime} D^{\prime}$ be two quadrilaterals in $\mathbb{R} P^{2}$. There is then a unique projective transformation $t$, which maps $A$ to $A^{\prime}, B$ to $B^{\prime}, C$ to $C^{\prime}$, and $D$ to $D^{\prime}$.

This fundamental theorem explains why all quadrilaterals are congruent (projective congruent) and all conical sections are projective congruent (Figure 4).
An illustration of the projective congruence of a combination of triangle and rectangle through projective transformation is provided in the projective matrix and Figure 5.

$$
t:[x] \longrightarrow[A x]
$$




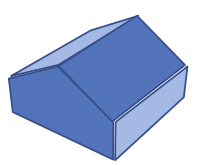

(a)

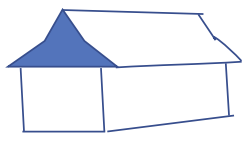

(b)

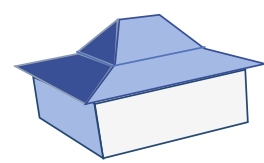

(c)

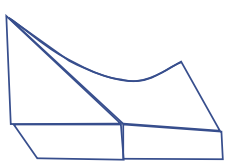

(d)

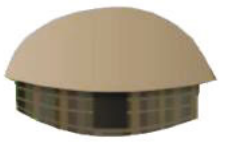

(e)

Figure 6: Simple houses.

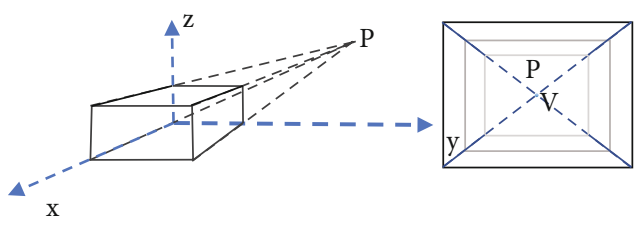

(a)

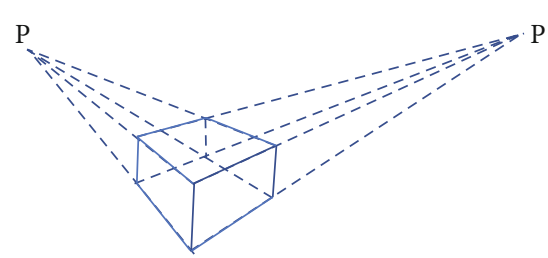

(b)

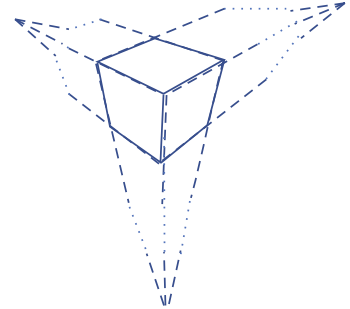

(c)

Figure 7: (a) One vanishing point; (b) two vanishing points; (c) three vanishing points.

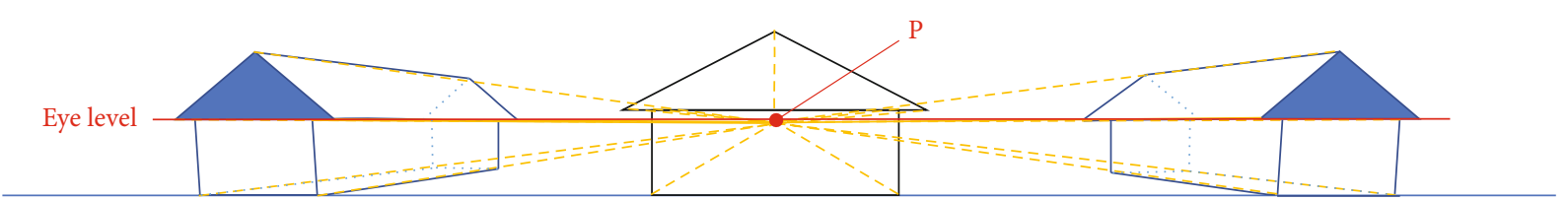

Figure 8: Three house diagrams with one vanishing point.

or

$$
T\left(\left[p_{1}, p_{2}, p_{3}\right]\right)=\left[\left\langle p_{1} p_{2} p_{3}\right\rangle\left(\begin{array}{lll}
a & b & c \\
d & e & f \\
g & h & i
\end{array}\right)\right] .
$$

\section{House Theory}

House theory was established by Chen and Ja'faruddin [10] based on traditional buildings and projective geometry. Traditional buildings are those with a unique architecture that reflects a nation's culture, identity, and history [23]. We used traditional house terms to define traditional buildings more specifically. Traditional houses are those built in a conventional manner. These houses are used by local people from generation to generation and have sociocultural functions. Every traditional house has a philosophy that underlies the design of the building [24]. From a projective geometry perspective, simple houses are divided as follows [10]:

(i) A simple house has a shape similar to that in Figure 6(a) up to rigid motions in $\mathbb{R}^{3}$. Geometrically, the roof of this simple house is a combination of a triangle and a parallelogram, and the body is a combination of a square and a rectangle

(ii) A simple house has a shape similar to that in Figure 6(b) up to rigid motions in $\mathbb{R}^{3}$. Geometrically, the roof of a simple house is a combination of trian-

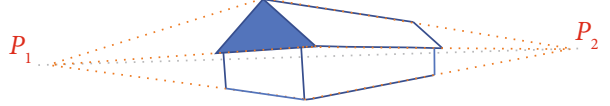

FIGURE 9: Two vanishing points.

gles, trapezoids, and rectangles, and the body is a combination of two rectangles

(iii) A simple house has a shape similar to that in Figure 6(c) up to rigid motions in $\mathbb{R}^{3}$. Geometrically, the roof of a simple house is a combination of two different trapezoids, and the body is the combination of two rectangles

(iv) A parabola simple house has is a shape similar to that in Figure 6(d) up to rigid motions in $\mathbb{R}^{3}$. Geometrically, the roof of a type 4 simple house is a triangle and parabolic trapezoid combination, and the body is a combination of two trapezoids

(v) A paraboloid simple house has a shape similar to that in Figure 6(e) up to rigid motions in $\mathbb{R}^{3}$. Geometrically, the roof of a paraboloid simple house is a paraboloid, and the body is a cylinder

In this paper, we explored traditional houses in Indonesia. The collection of traditional houses will enrich the house diagram models, facilitating the categorization and definition of building numbers and projective coordinates as novel mathematical concepts. 


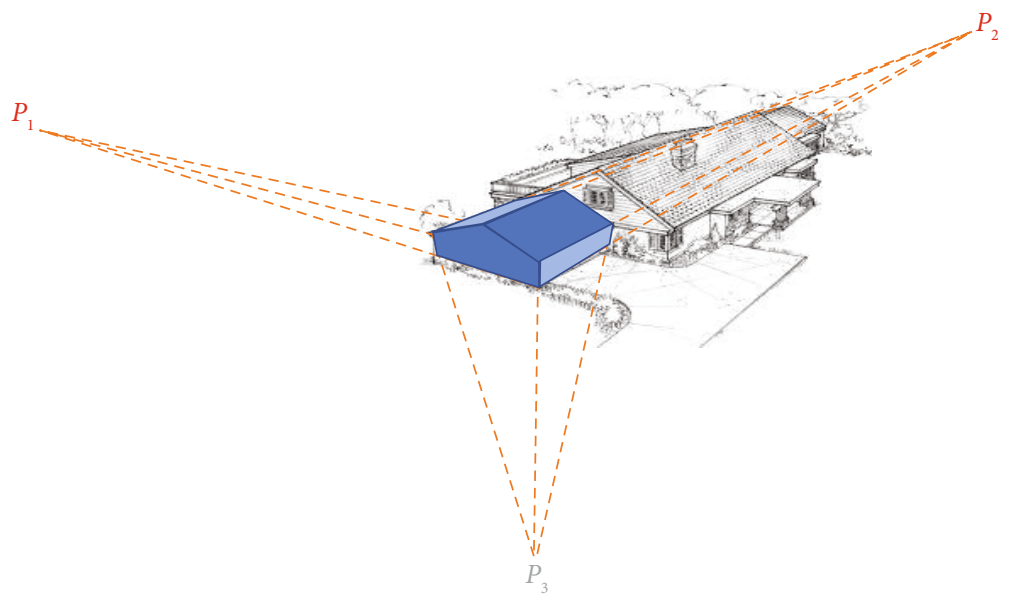

FIGURE 10: Three vanishing points.

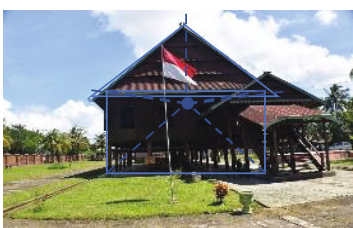

(a)

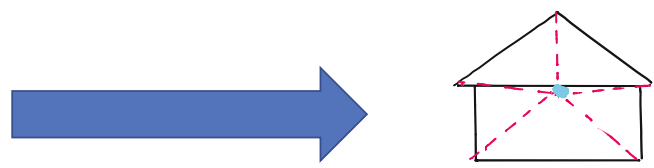

(b)

Figure 11: (a) $\widehat{A}_{1}$ and (b) $\widehat{A}_{1}^{\prime}$.
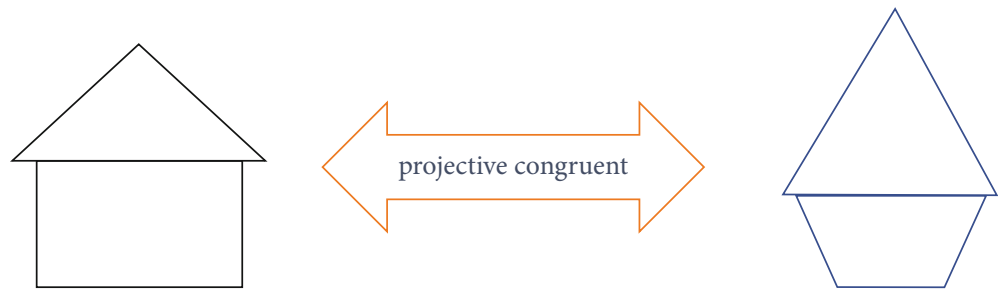

Figure 12: Projective congruent.

\section{Perspectives in Projective Geometry}

The vanishing point is a single point in Figure 7 at which two parallel lines (or line segments) in the scene appear to meet [25]. A vanishing point is a point on the image plane of a perspective drawing where the two-dimensional perspective projection of parallel lines in three-dimensional space appears to converge.

However, because the view of houses depends on the angle of perception, the image of a simple house should be defined based on three different perspectives.

5.1. Perspective from One Vanishing Point. If $P$ is the center of a vanishing point, then the images of the house with one vanishing point are as illustrated in Figure 8.

5.2. Perspective from Two Vanishing Points. If two points, $P_{1}$ and $P_{2}$, are the centers of the vanishing points, then the image of a house with two vanishing points is as illustrated in Figure 9.

5.3. Perspective from Three Vanishing Points. If the three points, $P_{1}, P_{2}$, and $P_{3}$, are the centers of the vanishing points,

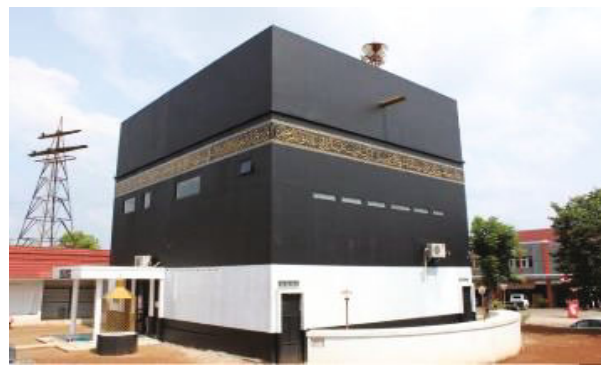

FIgure 13: Masjid Ka'ba Subang, Indonesia [26].

then the image of a house with three vanishing points is as illustrated in Figure 10.

\section{Materials and Method}

Data were collected from documentation, observation, and interview. The observations of several traditional buildings in Indonesia were based on camera images, aerial camera 


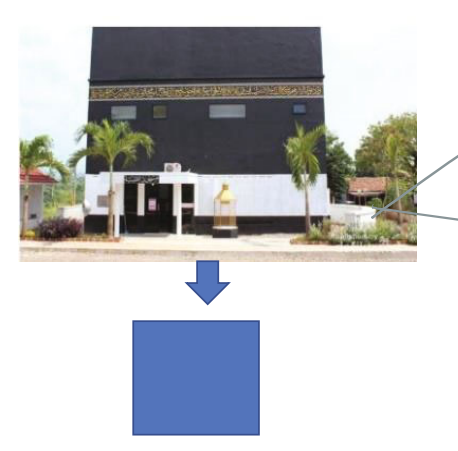

(a)

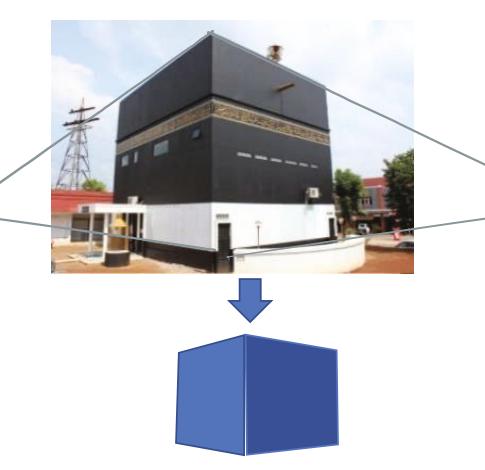

(b)

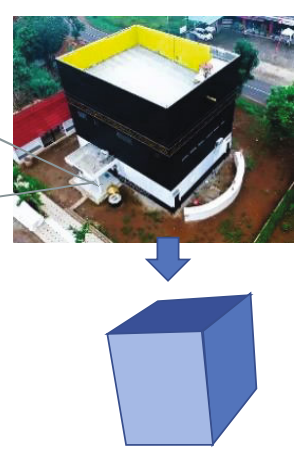

(c)

FIGURE 14: Cubic simple house diagram: (a) one vanishing point, (b) two vanishing points, and (c) three vanishing points.

images (drone camera), and documentation techniques. The sample of this research is classified into two groups. The first group is the traditional houses with terraces that built on poles, and the second group is the traditional houses without terraces which the houses are directly sit on the pillars above ground. An aerial camera was used to obtain pictures from above and from the other sides of traditional buildings. To complete and verify data, the researcher interviewed local people living in traditional houses and consulted local scholars. Data on traditional buildings were also obtained from local literature and the internet. Some interviews were conducted online because of the COVID-19 pandemic. Data on the traditional building were analyzed using descriptive methods.

\section{Results and Discussion}

The building numbers and projective coordinates were based on the Indonesian traditional house structure. The traditional houses are presented in the form of house diagrams from an ethnomathematical perspective and then with different projections and vanishing points.

Definition 1. Let $\widehat{A}_{\alpha}$ be the picture of a traditional house and $\widehat{A}_{\alpha}^{\prime}$ be the simple projection, called a house diagram, of the house onto a plane, where $\alpha$ is the number of vanishing points.

A photograph of a traditional house in Indonesia $\widehat{A}_{1}$ is presented in Figure 11(a), and the house diagram $\widehat{A}^{\prime}{ }_{1}$ of $\widehat{A}_{1}$ (one vanishing point) is presented in Figure 11(b).

Based on the definition of projective transformations, the combination of a triangle and trapezoid is projective congruent with a rectangular triangle (Figure 12).

This definition was used to develop building numbers. The arrangement of these simple house categories was based on the categorization rule.

7.1. Categorization Rule. The categorization of simple houses was based on basic geometrical figures such as rectangles, triangles, the combination of rectangular triangle shapes, rectangular shapes, rectangular-triangular trapezoid shapes, rectangular trapezoid shapes, and shapes with curved edges.

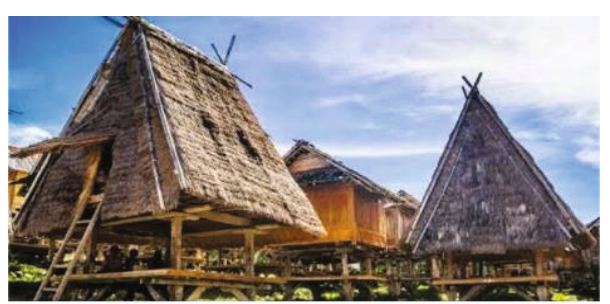

Figure 15: Uma Lengge [28].

7.1.1. Simple House I (Cubic Simple House). A simple house I has house diagram as a cubic (Figure 13). It is the most basic form of simple houses. The model of a simple house diagram should represent the majority belief of Indonesian people. The majority of Indonesian people are Muslims. Muslims believe that the most important building in this world is Kaaba in Mecca. Kaaba is the word for a cube in Arabic. This holiest shrine in Islam is a square building, elegantly draped in a silk and cotton veil. This building is located in Mecca, Saudi Arabia, not in Indonesia. However, Muslims are spiritually close to this sacred house and pray in this direction.

Communities in Indonesia have built masjids (mosques) that are similar to the Kaaba. The sample of this model is Masjid Ka'ba that located in Subang, Indonesia. This mosque directly sits on the pillars above ground.

Simple house I and house diagrams are presented in Figure 14. The figures of the building are presented from three different perspectives, codified in the diagrams. The house diagram in one vanishing point forms a square, whereas the house diagrams from two and three perspectives are viewed as cubes.

Traditional dwellings in Indonesia are not typically cubic simple houses because the seasons of Indonesia require a roof that drains easily during the rainy season and releases heat during the dry season. This cubic simple house was selected as the first type of simple house for two reasons. First, the majority of traditional buildings in Indonesia have a cubic main building, which is the building that is lived in. Second, most people in Indonesia are Muslim and believe that the most sacred building is the Kaaba in Mecca.

7.1.2. Simple House II (Triangular Simple House). The diagram of simple house II from one vanishing point shows it 


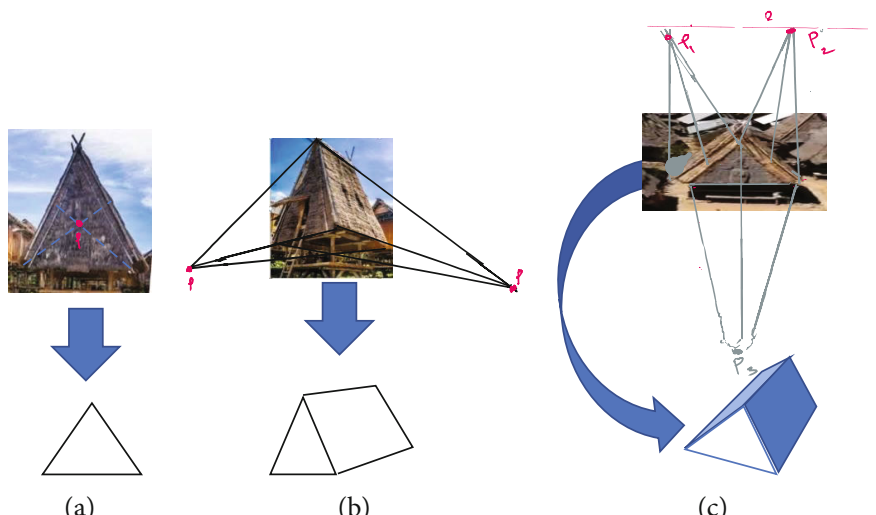

(a)

(b)

(c)

FIGURE 16: Uma Lengge from three different perspectives.

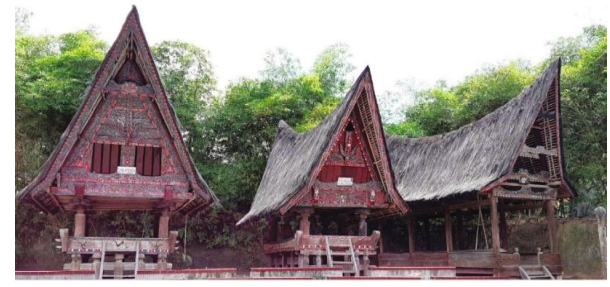

Figure 17: Batak Toba traditional houses [29].

as a triangle. An example of this simple house is the Uma Lengge presented in Figure 15. Uma Lengge are traditional houses in Bima District, West Nusa Tenggara, Sumbawa Island. This traditional house was built on poles. These traditional house functions are used for food storage and house members of the Mbojo tribe. These traditional houses are made of wood with thatched walls, and they have a triangular prism shape [27].

The pictures of Uma Lengge in Figure 16 show three vanishing points. Figure 16(a) displays the Uma Lengge in one vanishing point. The house diagram shows it as a triangle. Figure 16(b) displays the traditional house with two vanishing points. From this perspective, the house diagram displays a combination of a triangle (front house) and rectangles (right side and left side). Figure 16(c) presents the traditional house from three vanishing points. The house diagram shows a combination of a triangle and two rectangles. Simple house I is the traditional house in Indonesia with the simplest house diagram.

7.1.3. Simple House III. Simple house III has a triangulartrapezoidal shape from the front view. Batak Toba traditional houses are examples of this traditional house (Figure 17). The front part of a Batak Toba is triangles on the upper side and rectangular on the lower side.

This traditional house was built on poles. The roof shape of this traditional house has a slight curve. The roof has a sharp angle that is more protruding at the front than at the back. The back is higher than the front side. The unique shape of the roof has a philosophical meaning for this tribe. The higher roof casing in the back than in the front reflects that the Batak Toba people hope that their future generations will be more prosperous [30].
Figure 18 presents the house diagrams of simple house III from three different vanishing points. Figure 18(a) reveals that the house diagram from one vanishing point is a combination of triangles. Figures 18(b) and 18(c) present the diagrams from two and three vanishing points, respectively.

7.1.4. Simple House IV. The shape of the simple house IV combines a triangle and a rectangle. Some tribes in Indonesia use this model of a simple house. An example of this simple house can be observed in the Bone District, South Sulawesi Province. These houses are called Bola Soba, and they are presented in Figure 19. Bola Soba are monumental buildings for the Buginese People. This traditional house was built with terraces. The central part of this traditional house has a length of approximately $21 \mathrm{~m}$, with an $8 \mathrm{~m}$ long back yard. Local people preserve these buildings as historical buildings, cultural buildings, and museums. Bola Soba translates to "the house of friendship." The purpose of these houses was to entertain, receive, and welcome honorable guests from other kingdoms or countries.

Bola Soba is an example of simple house III. Figure 19 presents three images of Bola Soba from different perspectives. Through omission of the indentations or protrusions in the image of the building, Figure 19(a) presents the front view of the Bola Soba, the one vanishing point, and its house diagram. The form of the house diagram combines a triangle and a rectangle. The house diagram combining the front and left sides of the house (two vanishing points) is presented in Figure 19(b), and the diagram with three vanishing points presented in Figure 19(c) combines three parts of the house.

Verification of the traditional houses was performed using pictures of the real traditional house, presented in Figure 20. The figures illustrate the front and right sides and the top of the house (taken by aerial camera).

Furthermore, the results from interviews with the local people revealed that Buginese traditional houses represented the old faith of Buginese people, before Islam. They believed that their houses had to represent natural balances for their family to live in peace and harmony, which is why the body of their house forms a rectangle, in which every angle represents one of the four elements (fire, water, wind, and earth). Moreover, the roof represents the harmonious relationship between God, humans, and nature. Belief in God is the 


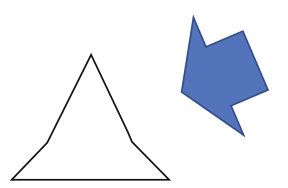

(a)
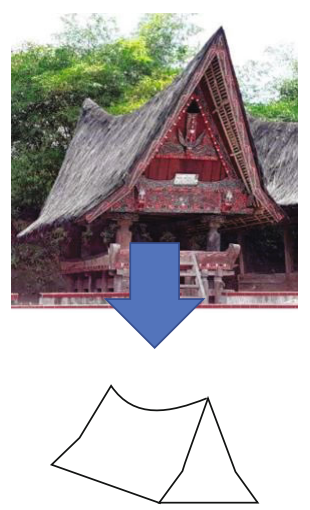

(b)

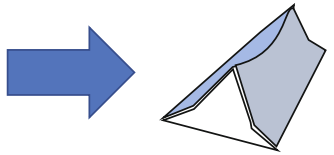

(c)

Figure 18: Batak Toba house and its house diagrams.

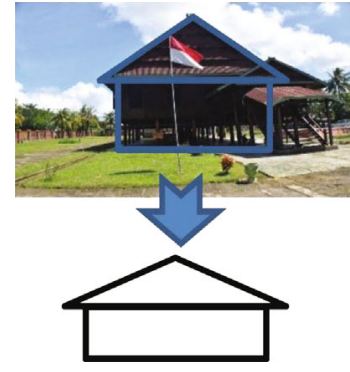

(a)

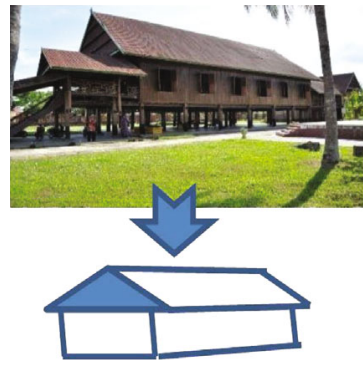

(b)

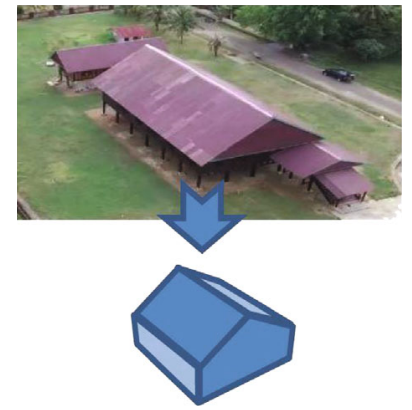

(c)

Figure 19: Bola Soba’s images.
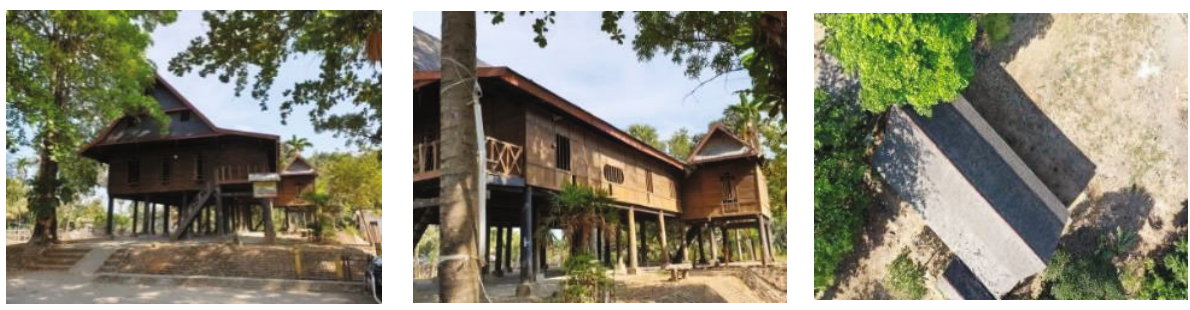

Figure 20: Buginese traditional house.

highest priority of Buginese people. This result was supported by Syarif s [17] description of the philosophy of sulapa eppa (rectangle) and by Yunus's [31] findings regarding the meaning behind Buginese traditional houses.

7.1.5. Simple House V. The house diagram of simple house IV from one vanishing point is defined by a combination of a triangle and two trapezoids. The Sao Mario house presented in Figure 19 is one example of simple house V. This traditional house, situated in Soppeng District in South Sulawesi Province, Indonesia, is also called hundred pillars because it has 119 pillars [32]. This building is used as a museum and tourist destination and hosts cultural events.

Figure 21 displays Sao Mario house from three different perspectives. The house diagrams of this traditional house with three different vanishing points are presented with indentations and protrusions avoided.
The second example of this simple house type is the Batak Toba house presented in Figure 22. Unlike simple house III Batak houses, these traditional houses are commonly constructed by the Batak tribe as a dwelling for the local people.

The house diagram of this Batak house from the front, as presented in Figure 23(a), has a geometrical form in which a triangle and two trapezoids are combined. This house diagram shape is projective congruent with the house diagram presented in Figure 23(a). From two and three different vanishing points, Figures 23(b) and 23(c) reveal that the roof of the traditional house has a slight curve.

7.1.6. Simple House VI. From one vanishing point, the geometric model of simple house VI combines two trapezoids and one rectangle. An example of this model is a Joglo house in which categorized as traditional house that directly built on the pillars above ground. The Joglo house presented in 


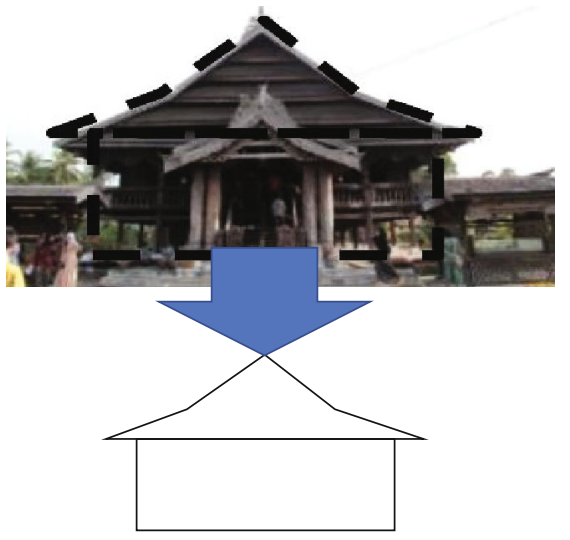

(a)

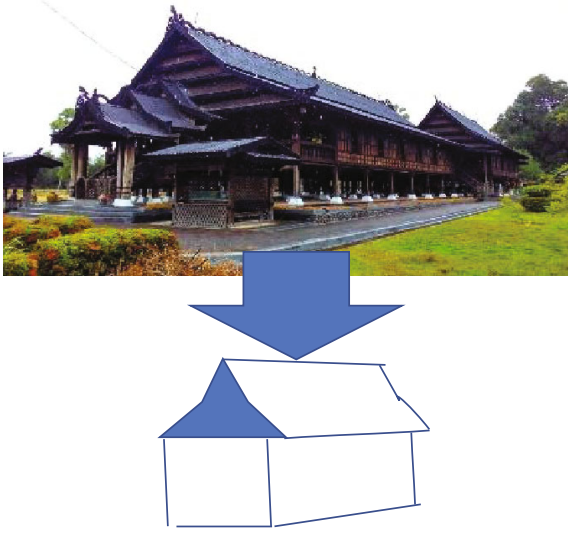

(b)

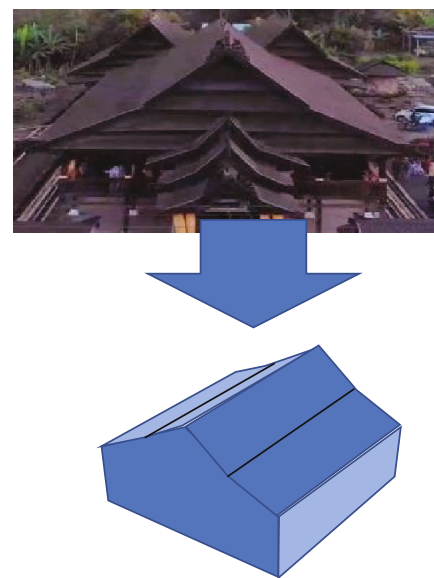

(c)

Figure 21: Mario house.

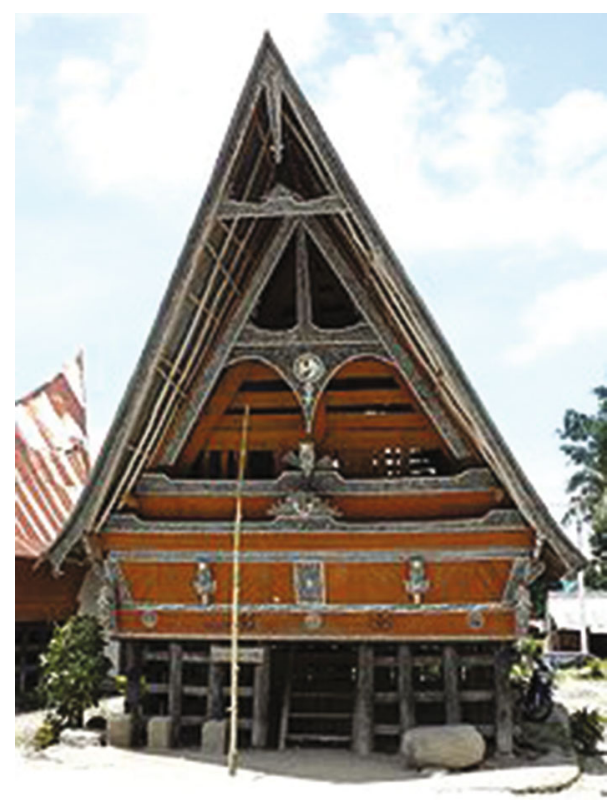

Figure 22: Batak Toba house.

Figure 24 is a traditional Javanese house located in Central Java, Indonesia. This traditional house shape was inspired by the shape of a high mountain in Java, symbolizing God's place among the ancient people of Java [33]. The projective coordinates of the traditional house were assessed.

Figure 24 represents a Joglo house from three perspectives. Figure 24(a) displays the Joglo house from one vanishing point, revealing a combination of two trapezoids and one rectangle. Figures 24(b) and 24(c) present house diagrams from two and three vanishing points, respectively.

The Tongkonan house displayed in Figure 25 is another example of simple house VI. This traditional house was built on the poles. This traditional house in South Sulawesi is accredited to the Toraja people or the Sa'dan Toraja. The pictures of South Sulawesi were taken using a phone camera and drone camera.
The shape of the front of this traditional house is in the form the combination of two trapezoids and a rectangle, and the roof is catenary. The shape of the roof is based on local people's beliefs. The roof of the Tongkonan house represents the sky in which they believe that their god arched the firmament down to the world. They believe that their god curved the sky, which is why they build the Tongkonan roof in a catenary shape. These interview results confirmed the findings of study by Palm [34], who reported that the Tongkonan house represents the macrocosmos and the roof represents the microcosmos. Furthermore, Palm wrote that the center of the house symbolizes an anak dara (girl), as a fertility symbol, and the northern part of the Tongkonan is associated with gods and the deified dead.

7.1.7. Simple House VII (Paraboloid Simple House). The simple house VII diagram displays a parabola-like or catenarylike curve. Examples of this simple house are Hanoi houses in Papua Province, Indonesia (Figure 26). Hanoi houses are among the most famous house types in Indonesia that directly built on the pillars above ground. The local people in Papua preserve these traditional structures as homes and places for the cultural events of the tribe. These traditional houses are divided into two categories: traditional houses for men are called Hanoi, and traditional houses for women are called Ebei.

The first image of a Hanoi house (Figure 26(a)) shows the front house of with one vanishing point. Figure 26(b) displays the house with two vanishing points. The third figure has three vanishing points. The three house diagrams of this traditional house are projective congruent with each other.

\subsection{Construction of Building Numbers and Projective Coordinates}

Definition 2. The house diagram of traditional houses can be divided into three parts: the front house, the side house (left or right sides), and the roof (Figure 27). 


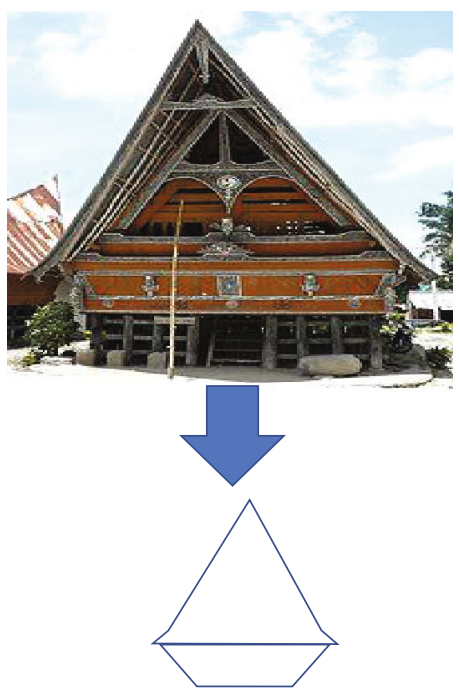

(a)

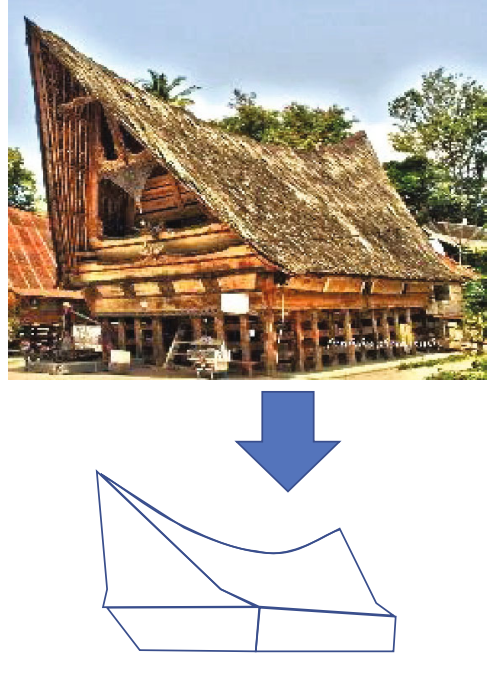

(b)

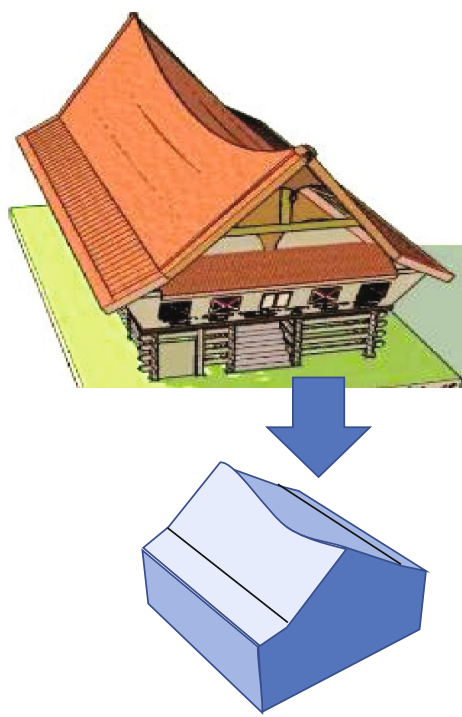

(c)

FIgURe 23: Batak Toba house from three different vanishing points.

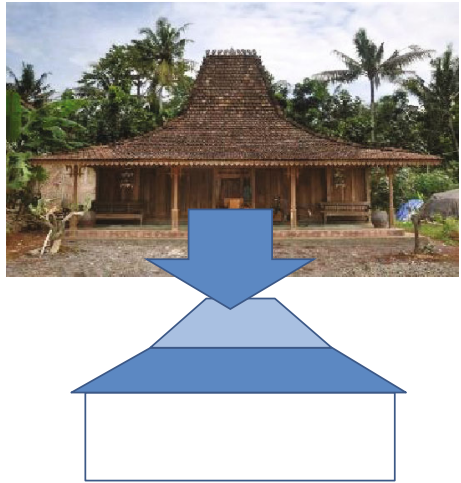

(a)

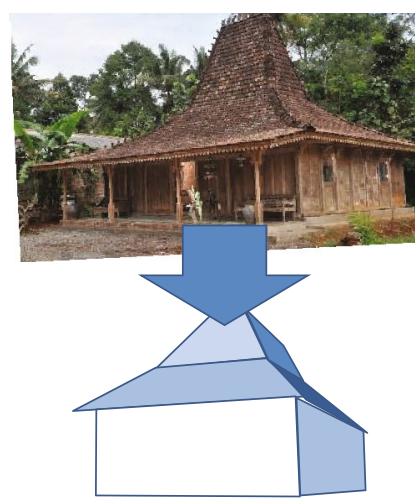

(b)

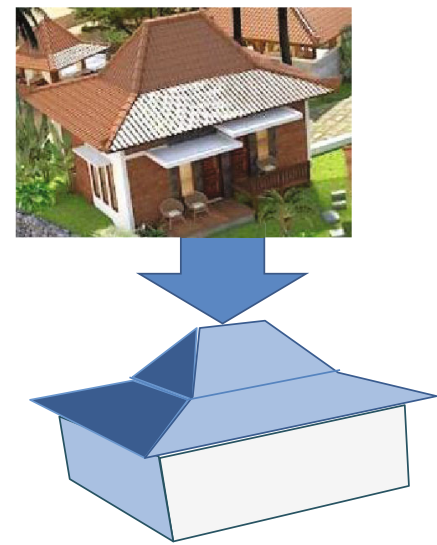

(c)

Figure 24: Joglo house.

Numerous traditional houses around the world have similar front-of-house shapes, such as the rectangular triangle. However, the side and top views differ (Figure 28).

Therefore, traditional houses cannot be categorized into a certain model without an assessment of at least two views. These findings also suggest that the front of the house is an identity component in house theory. Simulations with traditional house diagrams were constructed to further explore this idea as presented in Figures 29-35.

The figures reveal that the simple houses V and VI each have two branches, whereas the other simple house types do not have branches. Simple house VII is only represented in one house diagram because the house diagrams from two and three vanishing points are projective congruent.

Definition 3. The building numbers of a house diagram $\widehat{A^{\prime}}{ }_{\alpha \_\beta}$ are in the form of $\widehat{n}_{\alpha_{-} \beta}$, where $\alpha$ is the index of a building of the same type, $\beta$ is the number of vanishing points, and $n$ is a natural number.

In this article, $n=1,2,3,4,5,6$, and 7 . The procedure used to construct the building numbers is as follows:

(1) The most basic constructions of ${\widehat{A^{\prime}}}_{\alpha_{-} \beta}$ was identified, starting from rectangular, triangle, the combination of triangle-rectangular, rectangularrectangular, and so on. Every building of every house type was numbered starting with the front door. The front of the house was assigned the first number for three reasons

(a) Indonesian people always focus on the door shape. Therefore, making the front door as beautiful as possible is crucial. Furthermore, it is polite to enter the house through the front door 


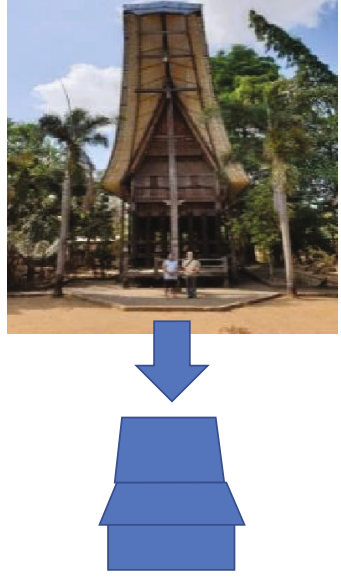

(a)

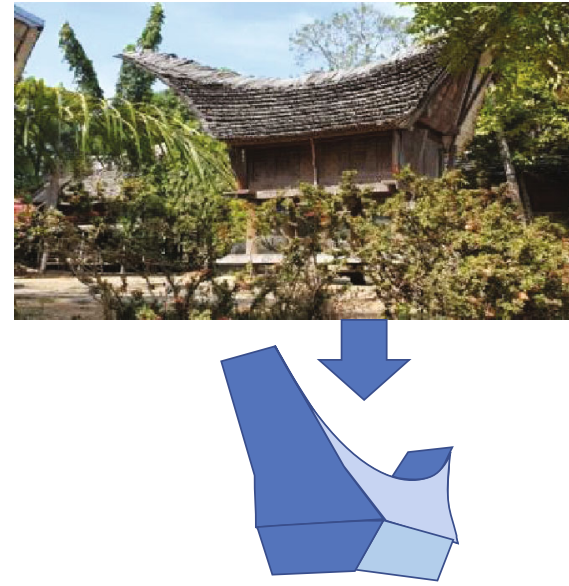

(b)

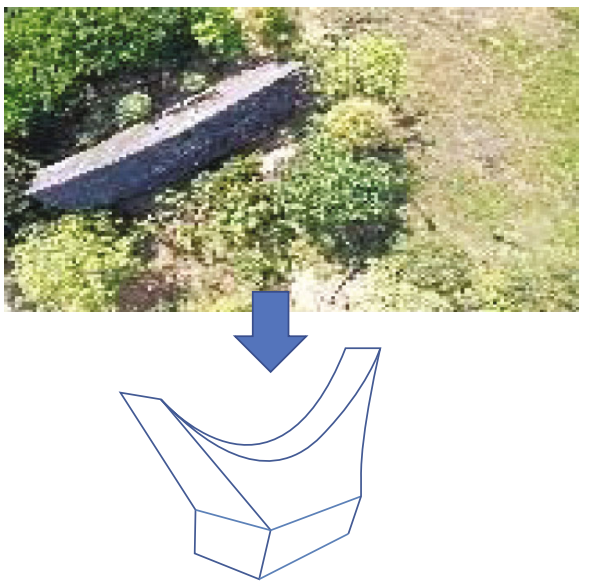

(c)

FIgUre 25: Tongkonan house.
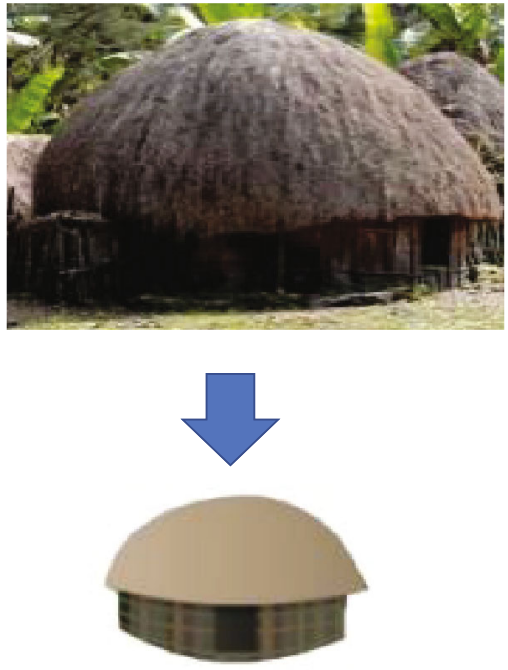

(a)
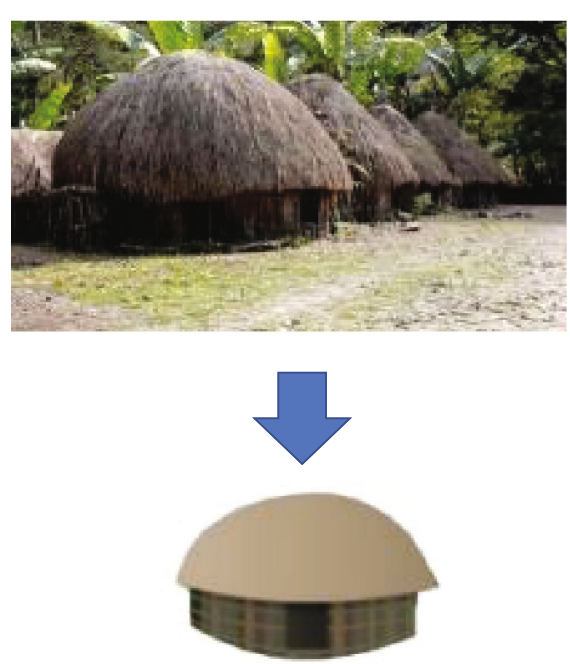

(b)
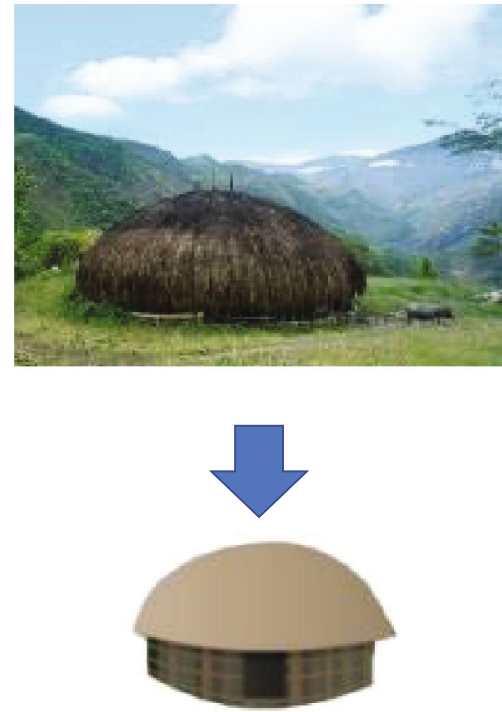

(c)

Figure 26: Hanoi house.

(b) The construction of the front door is based on the local people's beliefs

(c) From a projective geometry perspective, the front door can be viewed as Lines in $\mathbb{R} P^{2}$ (i.e., planes in $\mathscr{R}^{3}$ through the origin). Therefore, some planes are parallel to the lines of the front door

(2) If the front sides of buildings were similar but the left and right sides were different, then $n$ was the same but the index numbers $(\beta)$ were different

(3) If the figure of a building was of the same building but from different perspectives (different house diagrams), then $n$ was the same, but the number of vanishing points $(\alpha)$ was different

(4) Three was the maximum number of vanishing points assessed in this study
Before further analysis of building numbers, we developed the basic principle of the construction of building numbers. The building numbers based on the equivalence between the number of parts of buildings and the number of vanishing points were defined as complete images.

Definition 4 (Complete image). The number of vanishing point(s) is equivalent to the number of parts of the building.

Examples of Definition 4 are presented in the following section.

Figures 36(b)-38 are the complete images because this image has one vanishing point with just one part of the house diagram. However, the images in Figures 36(a) and 36(c) are not complete because they are viewed from one vanishing point but the house diagrams are in two parts. 


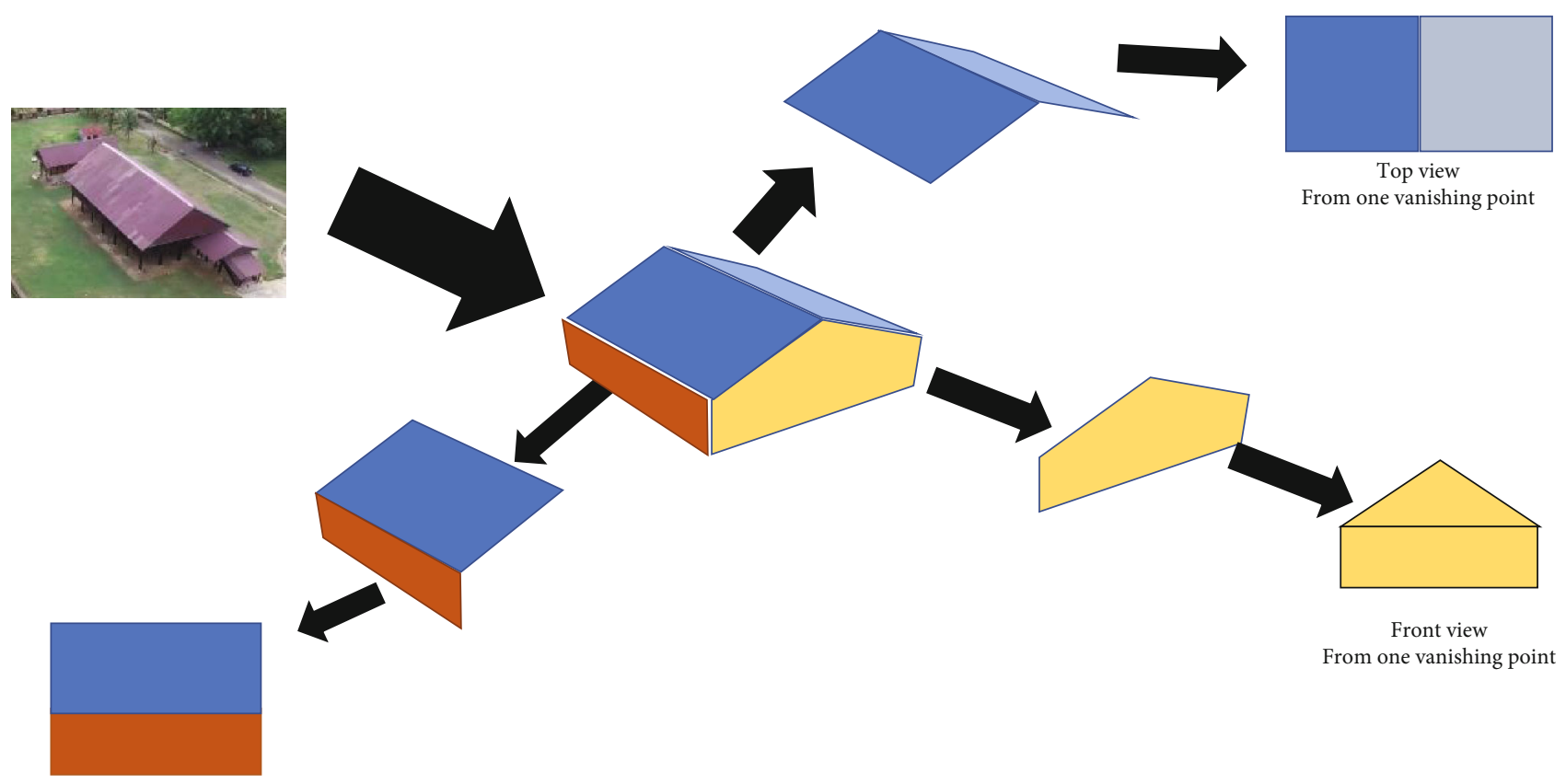

Left or right view

From one vanishing point

FIGURE 27: House diagram's parts.

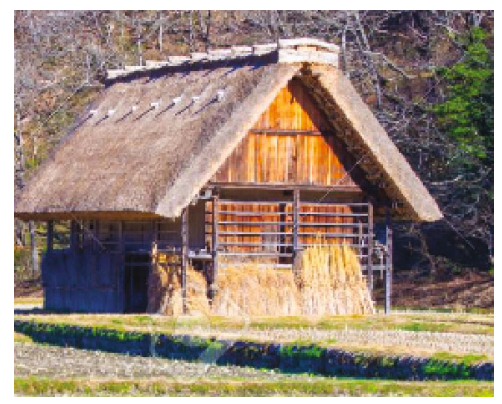

(a)

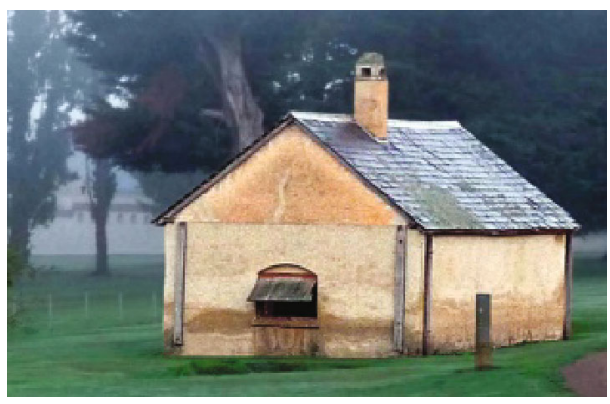

(b)

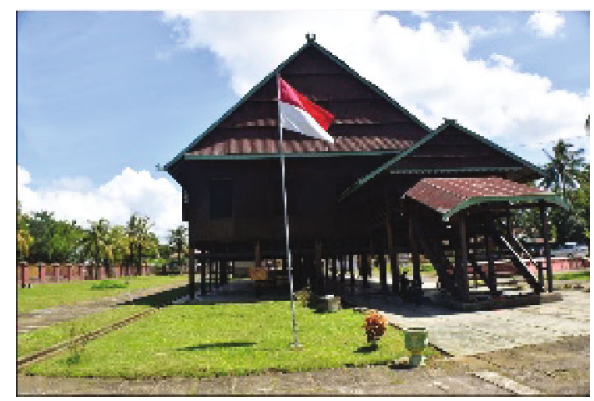

(c)

FIgUre 28: (a) Gassho Zukuri Style, Japan [7, 13] (b) An Old house in Tazmania, Australia, (c) Bola Soba, Indonesia [10].
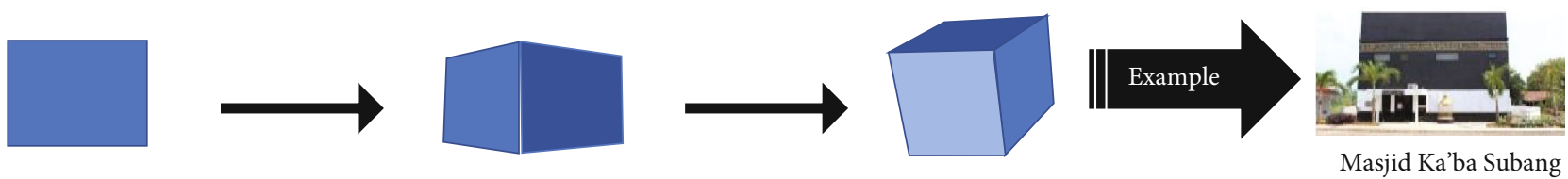

FIGURE 29: House diagrams of simple house I. 


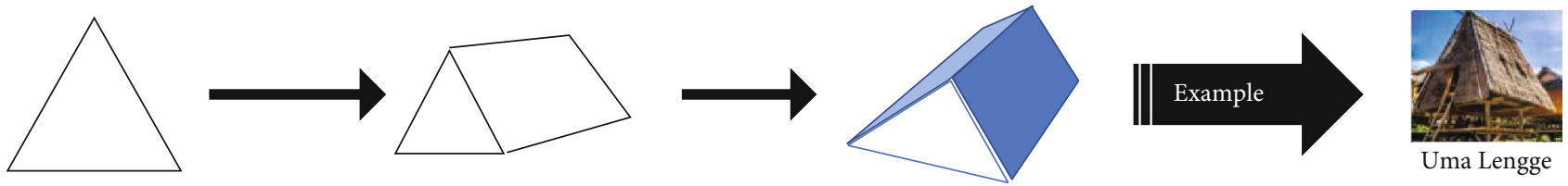

FIGURE 30: House diagrams of simple house II.
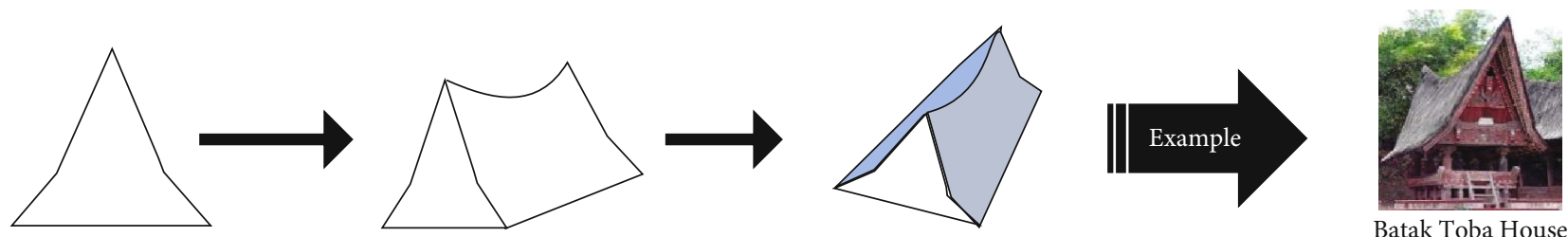

FIGURE 31: House diagrams of simple house III.
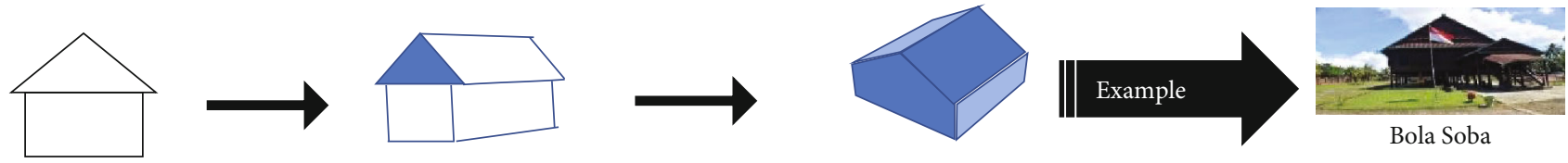

FIGURE 32: House diagrams of simple house IV.
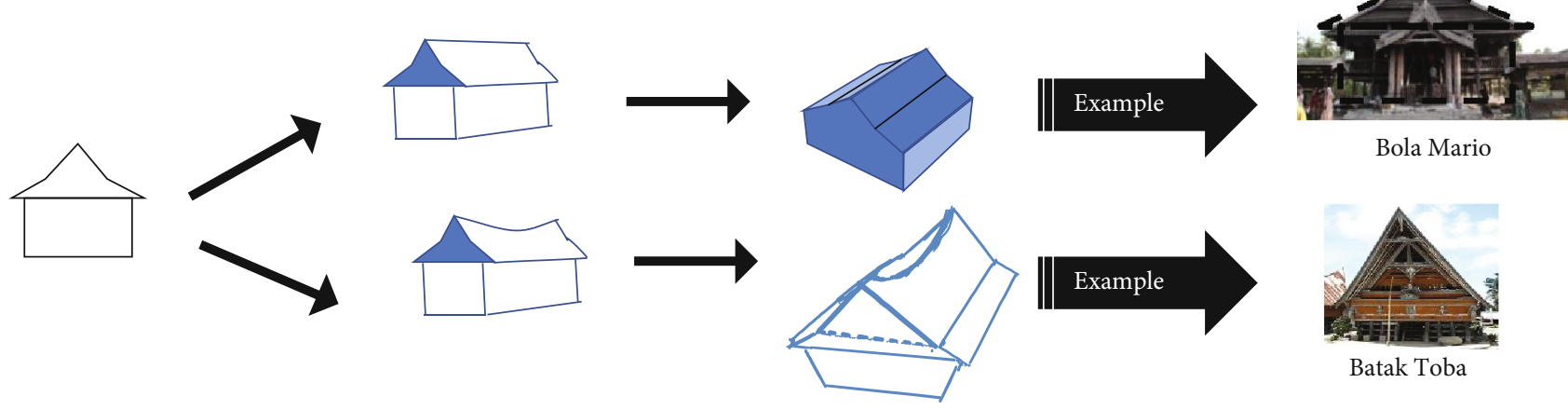

\section{Example}

Example

Batak Toba House

FIGURE 33: House diagrams of simple house V.
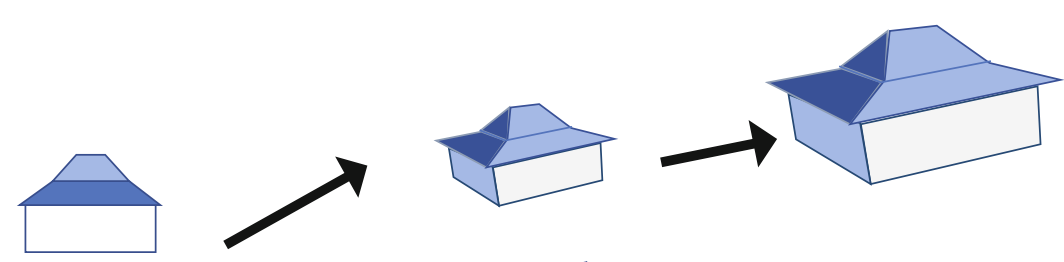

Example
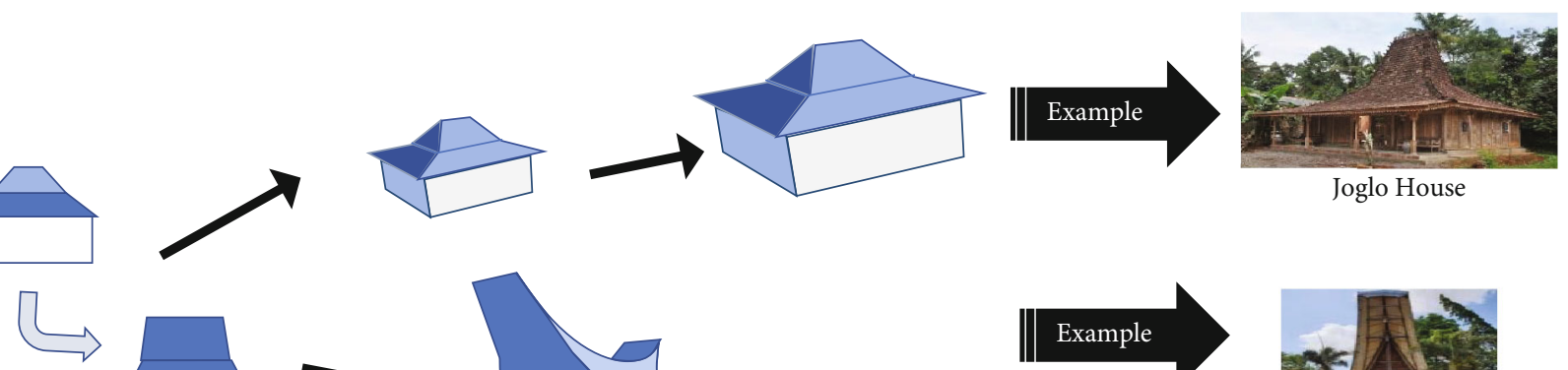

Projective
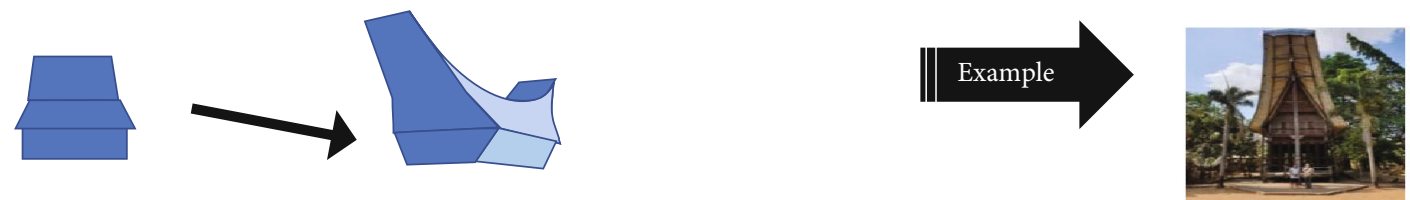

Tongkonan

Figure 34: House diagrams of simple house VI. 

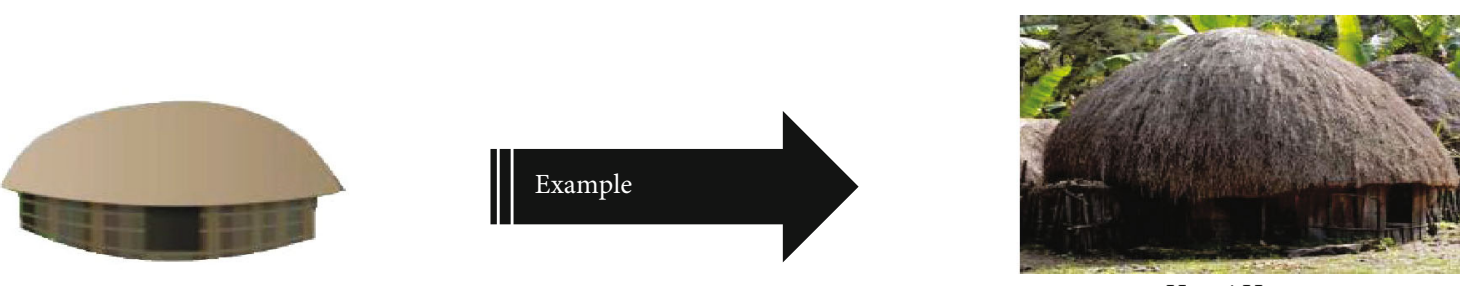

Hanoi House

Figure 35: House diagrams of simple house VII.

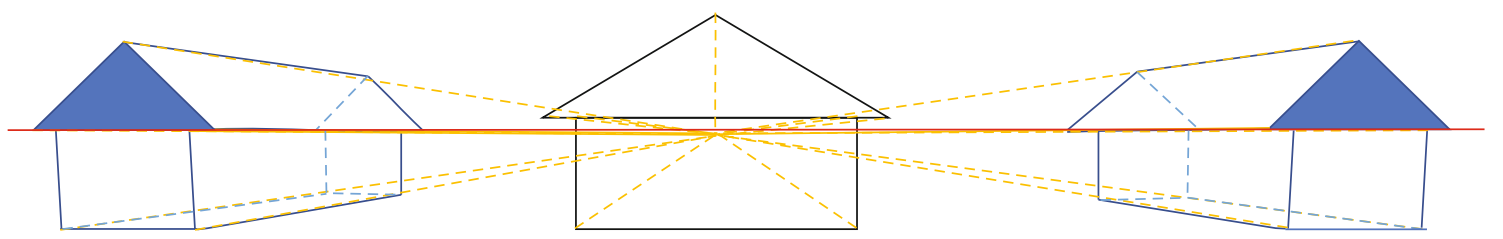

(a)

(b)

(c)

FIGURE 36: House diagrams.

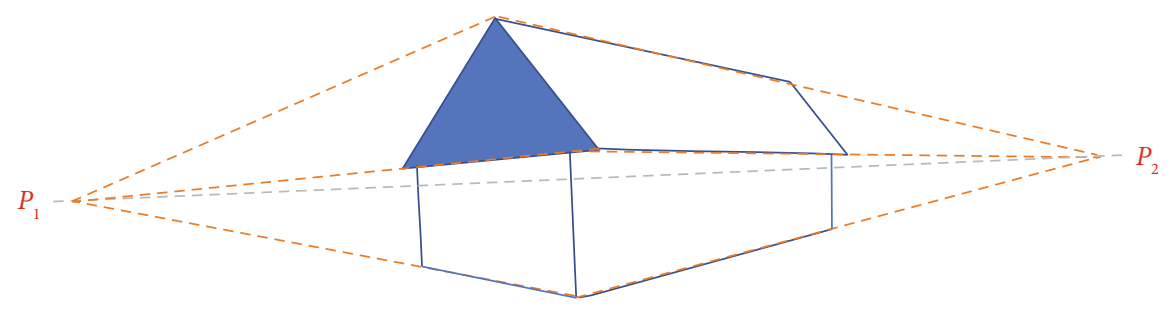

Figure 37: Complete image.

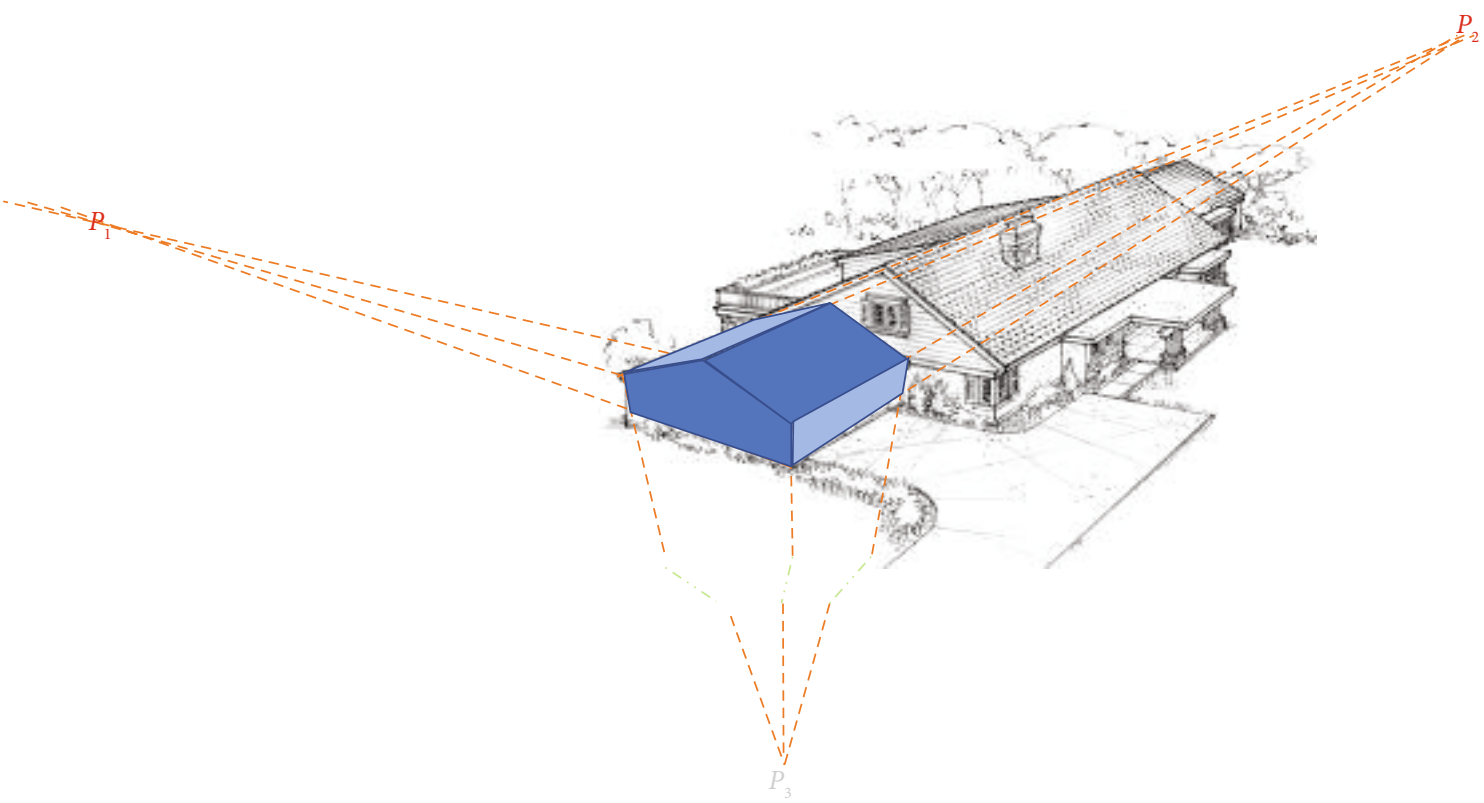

Figure 38: Complete image.

Figures 37 and 38 are complete images because the figures display two vanishing points in two parts and three vanishing points in three parts in the house diagrams, respectively.
7.3. Construction of Building Number $\widehat{1}_{\alpha_{-} \beta}$. Figure 39 illustrates how to construct building numbers from cubic simple houses. This figure displays a front view image with one vanishing point. By applying procedure 1, we obtained 


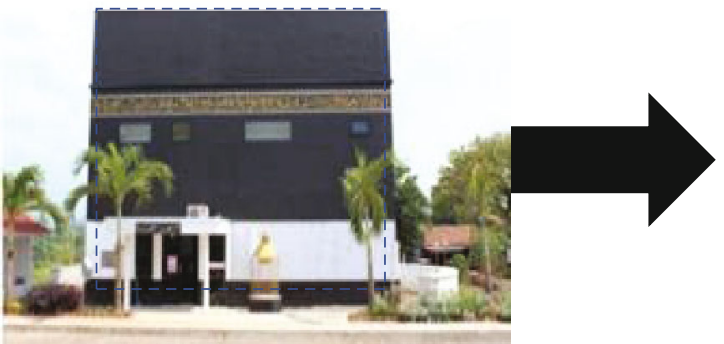

(a)

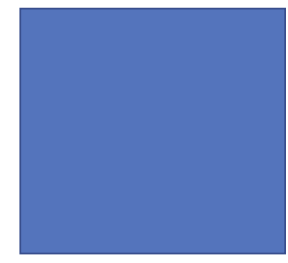

(b)

Figure 39: Construction building number $\widehat{1}_{1_{1} 1}$.

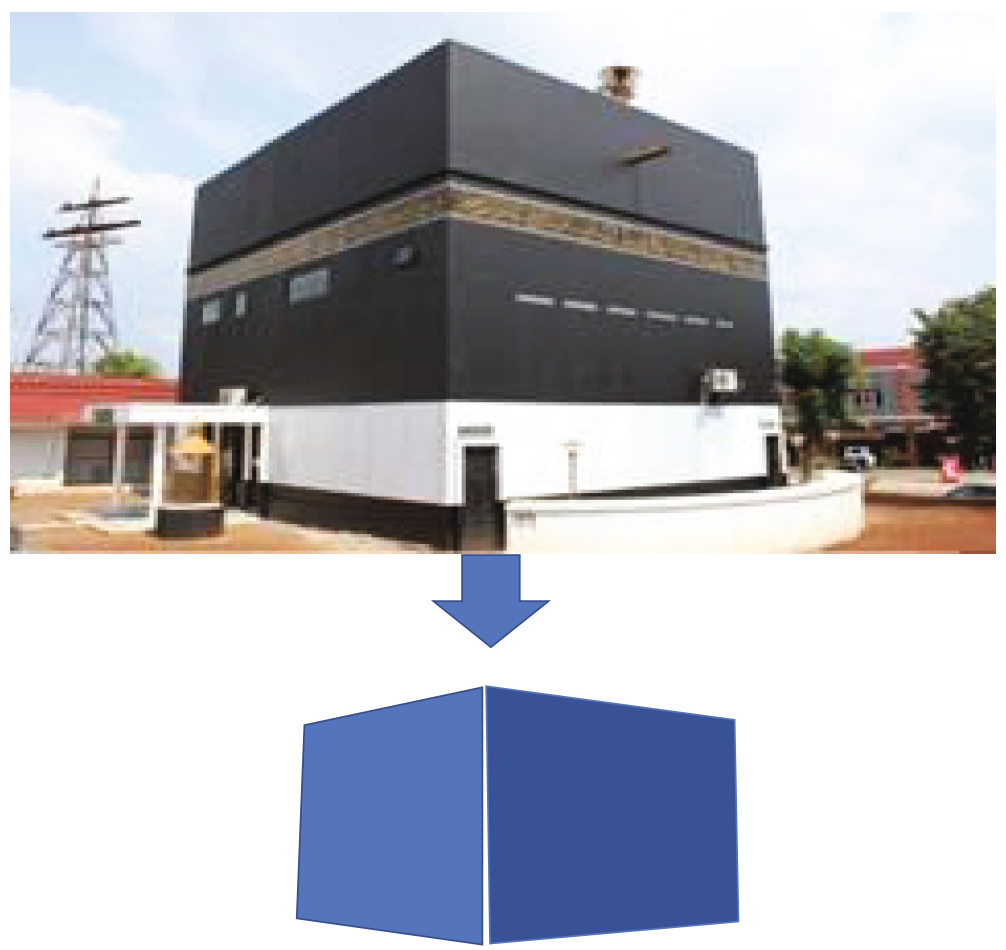

Figure 40: Construction building number $\widehat{1}_{1 \_2}$.

a rectangular house diagram. This house diagram was the first basic house diagram in one vanishing point, and the index was 1 , codified as building number $\widehat{1}_{1_{-1}}$.

Figures 40 and 41 are similar cubic simple houses, but with two and three vanishing points. We can obtain the building number $\widehat{1}_{1 \_2}$ and $\widehat{1}_{1 \_3}$ by applying procedures 2 and 3 , respectively.

7.4. Construction of Building Number $\widehat{2}_{\alpha_{-} \beta}$. Figure 42 illustrates the construction of building number $\hat{2}_{1_{1}}$. The figure presents a front view with one vanishing point (Figure 42(b)). We obtained a triangle (Figure 42(c)) by applying procedure 1 . This house diagram was the first basic house diagram for triangle traditional houses in one vanishing point, codified as building number $\widehat{2}_{1_{-1}}$.

Other building numbers for $\hat{2}_{\alpha_{-} \beta}$ are presented in Figure 43.

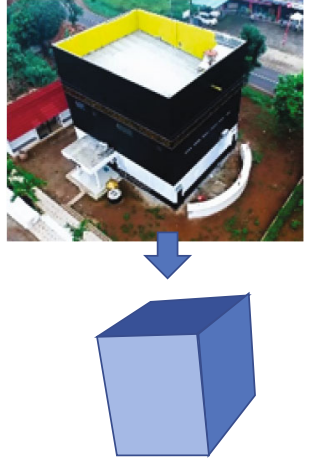

FIgURE 41: Construction building number $\widehat{1}_{1 \_3}$.

7.5. Construction of Building Number $\widehat{3}_{\alpha \_\beta}$. Simple house III was the model of the construction of building number $\widehat{3}_{\alpha_{-} \beta}$. The figure presents the image in front view with one 


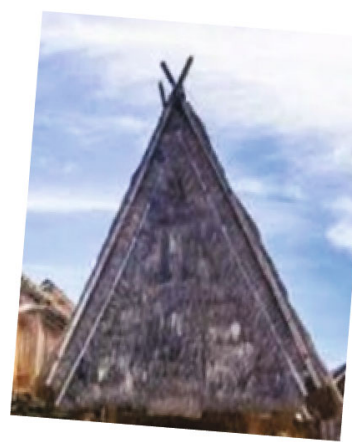

(a)

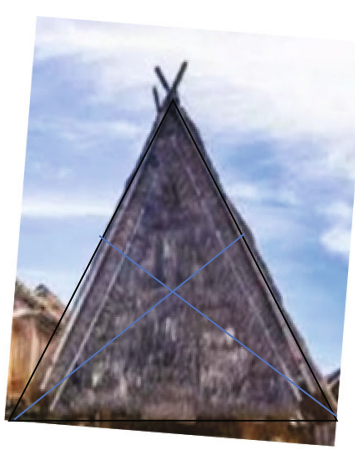

(b)

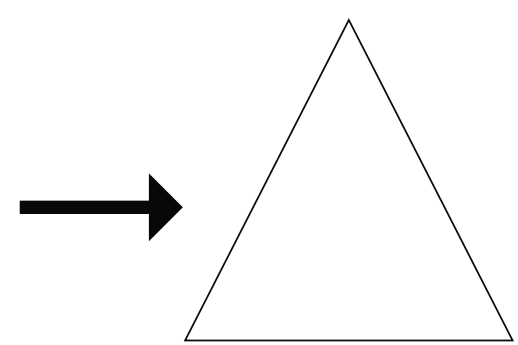

(c)

FIgURE 42: Construction building number $\widehat{2}_{1_{\_}}$.

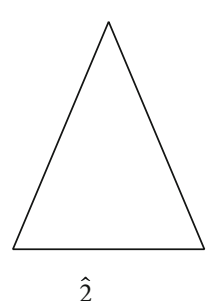

$\hat{2}_{1 \_1}$
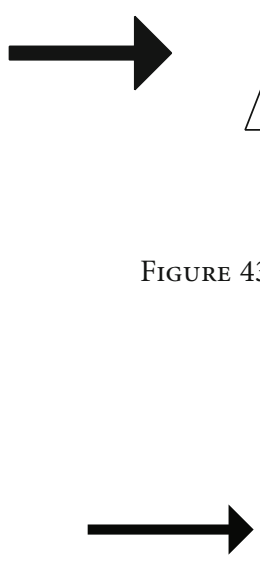

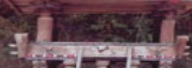

Batak Toba house

(a)

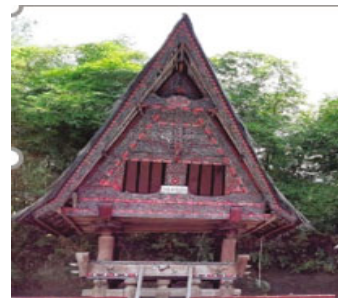

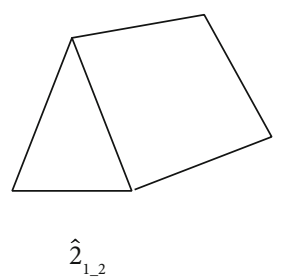
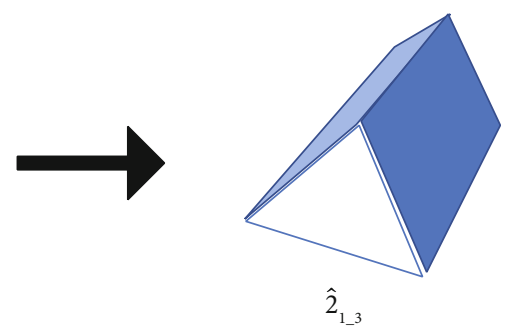

FIgURE 43: Construction building number $\widehat{2}_{\alpha_{-} \beta}$.

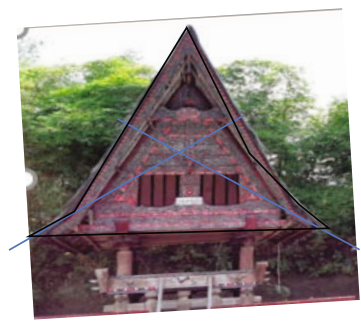

(b)

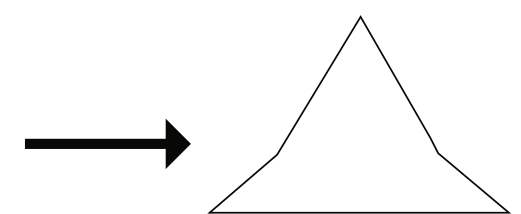

(c)

Figure 44: Construction building number $\widehat{3}_{1 \_1}$.

vanishing point (Figure 44(b)). We obtained a triangle house diagram (Figure 44(c)) by applying procedure 1 . This house diagram was the first basic house diagram for triangle traditional houses in one vanishing point, codified as building number 3 1_1.

Other building numbers for $\widehat{3}_{\alpha_{-} \beta}$ are presented in Figure 45.

7.6. Construction of Building Number $\widehat{4}_{\alpha_{-} \beta}$. Figure 46 illustrates the construction of building number $\widehat{4}_{1_{-} 1}$. This figure presents an image of a Bola Soba house in front view with one vanishing point (Figure 46(a)). We obtained a triangle rectangle combination (Figure $46(\mathrm{~b})$ ) by focusing on the main building and applying procedure 1; the relevant house diagram was obtained (Figure 46(c)). This house diagram was the first basic house diagram for the simple house type with one vanishing point, codified as building number $\widehat{1}_{1_{-1}}$. Figures 47 and 48 present the same traditional house but with two and three vanishing points, respectively. We obtained the building numbers $\widehat{4}_{1 \_2}$ and $\widehat{4}_{1 \_3}$ by applying procedures 2 and 3 , respectively.

7.7. Construction of Building Number $\widehat{5}_{\alpha_{-} \beta}$. The construction of building number $\widehat{5}_{\alpha_{-} \beta}$ was based on simple house IV. Figure 49 illustrates the construction of building number $\widehat{5}_{1 \_1}$. We obtained a triangle, trapezoid, and rectangle combination by applying the procedure point 1 (Figure 49(b)); the related house diagram (Figure $49(\mathrm{c})$ ) was obtained as a result. This house diagram is the first basic house diagram in this building number, codified as building number $\widehat{5}_{1_{1}}$. Figures 50 and 51 present the same traditional house with two vanishing points and three vanishing points, respectively. Therefore, we obtained building numbers $\widehat{5}_{1 \_2}$ and $\widehat{5}_{1 \_3}$ by applying procedures 2 and 3 , respectively.

The same procedure was also applied for the Batak Toba traditional house in Figure 52 to obtain $\widehat{5}_{2 \_1}, \widehat{5}_{2 \_2}$, and $\widehat{5}_{2 \_3}$. 


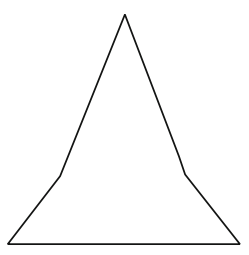

$\hat{3}_{1 \_1}$
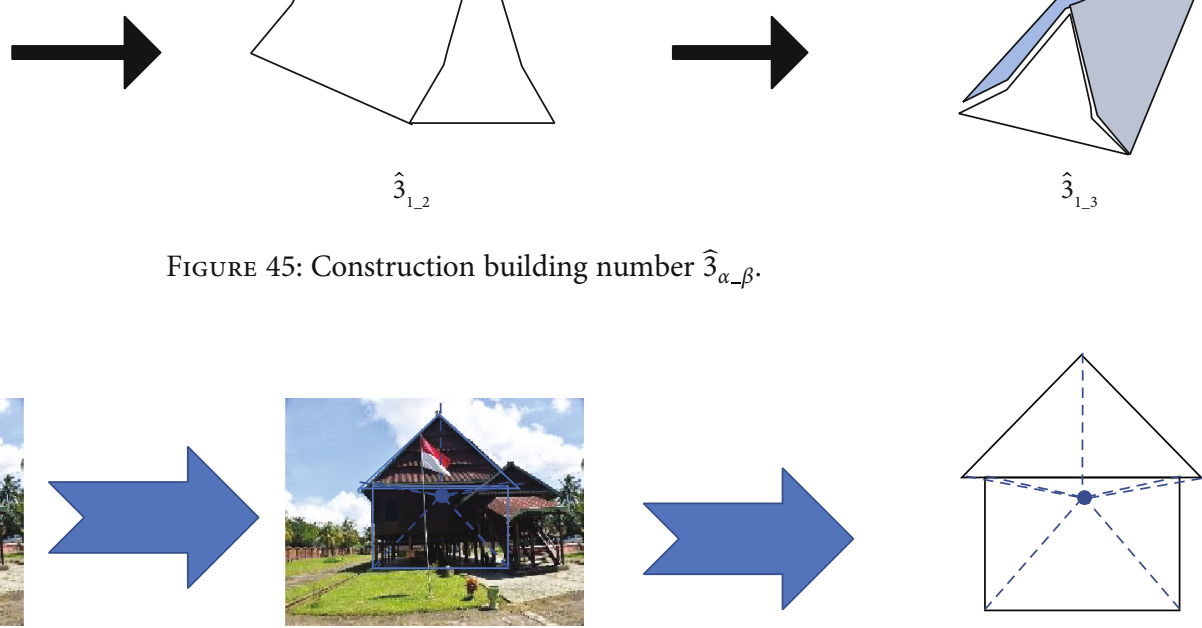

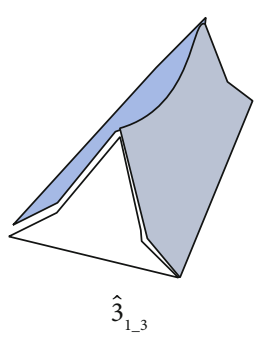

FIGURE 46: The construction of building number $\widehat{4}_{1_{1} 1}$.

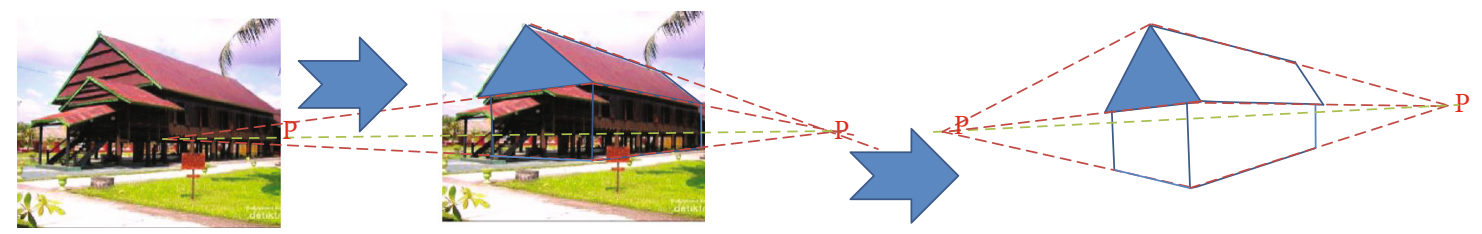

FIGURE 47: The construction of building number $\widehat{4}_{1 \_2}$.
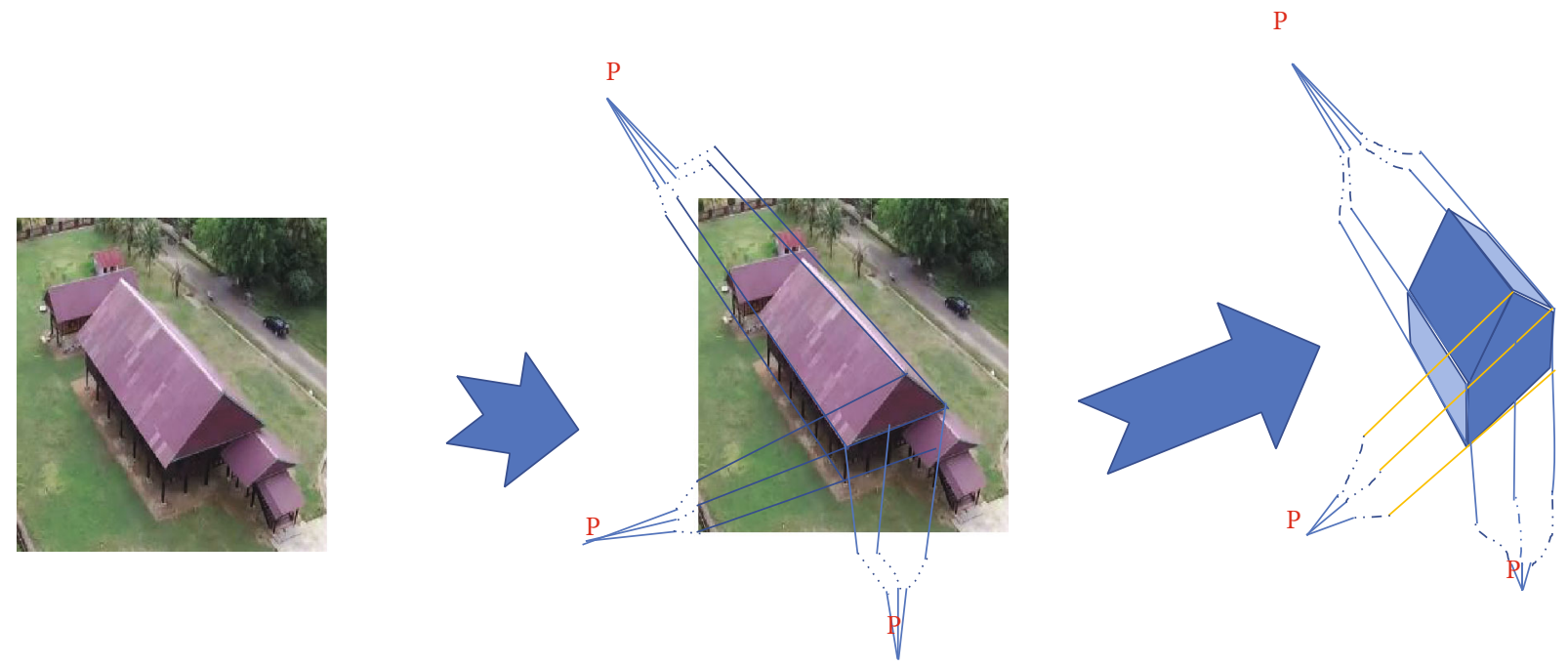

FIgURE 48: The construction of building number $\widehat{4}_{1 \_3}$.

Building number $\widehat{5}_{\alpha_{-} \beta}$ has two branches as in Figure 53.

7.8. Construction of Building Number $\widehat{\sigma}_{\alpha_{-} \beta}$. A Joglo house was selected for building number $\widehat{\sigma}_{\alpha_{-} \beta}$. The house diagram displayed in Figure 54 shows building number $\widehat{\sigma}_{1_{-1}}$, and the other two figures from different perspectives present building numbers $\widehat{\sigma}_{1 \_2}$ and $\widehat{\sigma}_{1 \_3}$. 


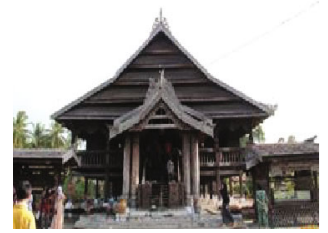

(a)
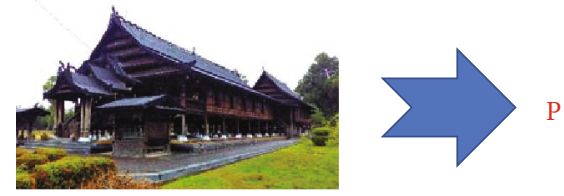

$P$

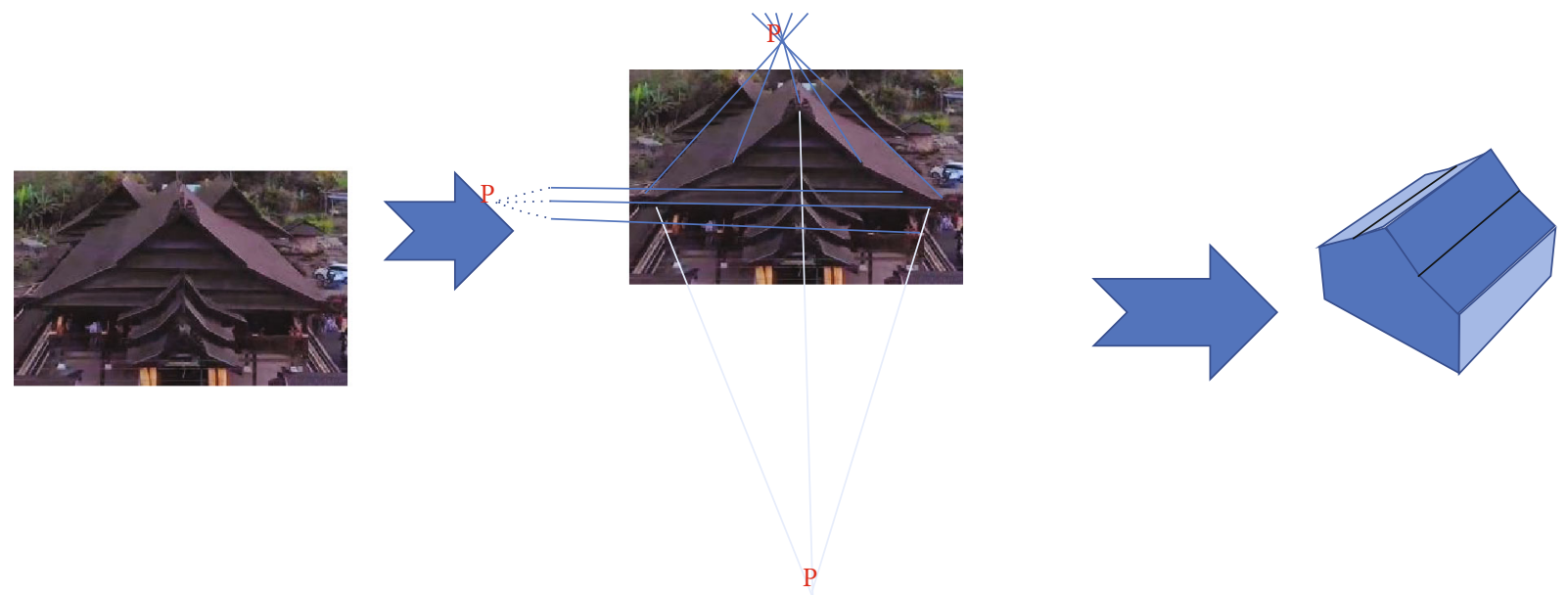

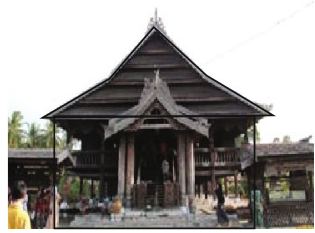

(b)
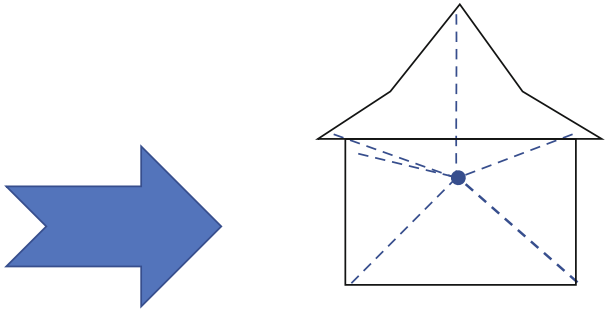

(c)

FIgURE 49: The construction of building number $\widehat{5}_{1 \_1}$.

FIGURE 50: The construction of building number $\widehat{5}_{1 \_2}$.

Figure 51: The construction of building number $\widehat{5}_{1 \_3}$.
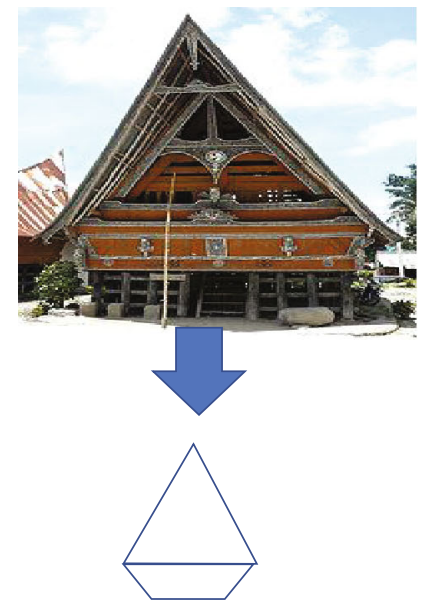

$\hat{5}_{1-1}$
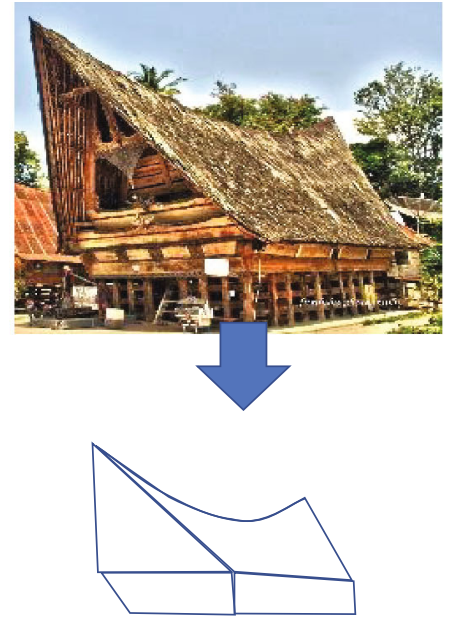

$\hat{5}_{2 \_2}$
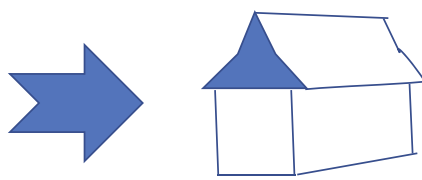

$\therefore P$ 

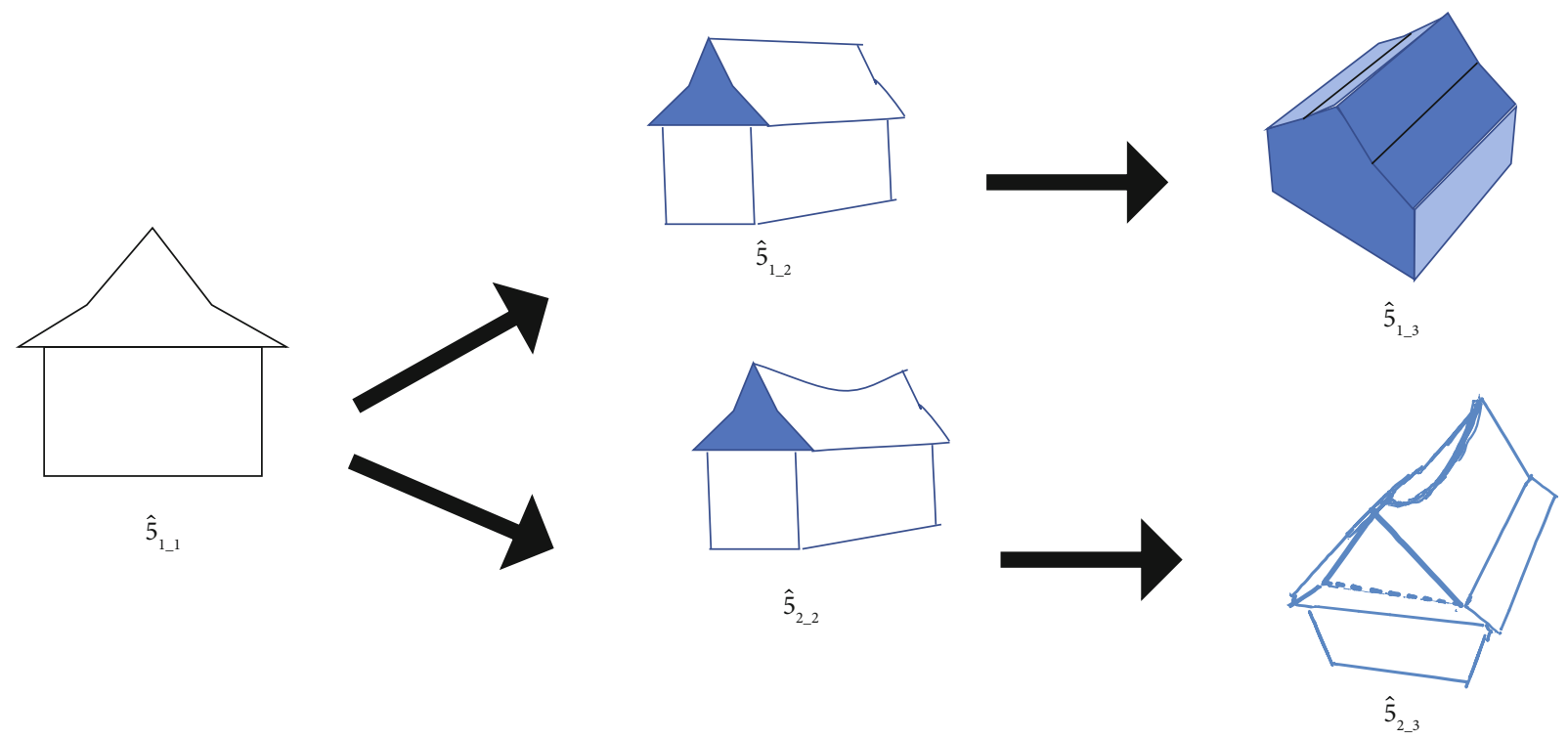

FIGURE 53: The construction of building number $\widehat{5}_{\alpha_{-} \beta}$.
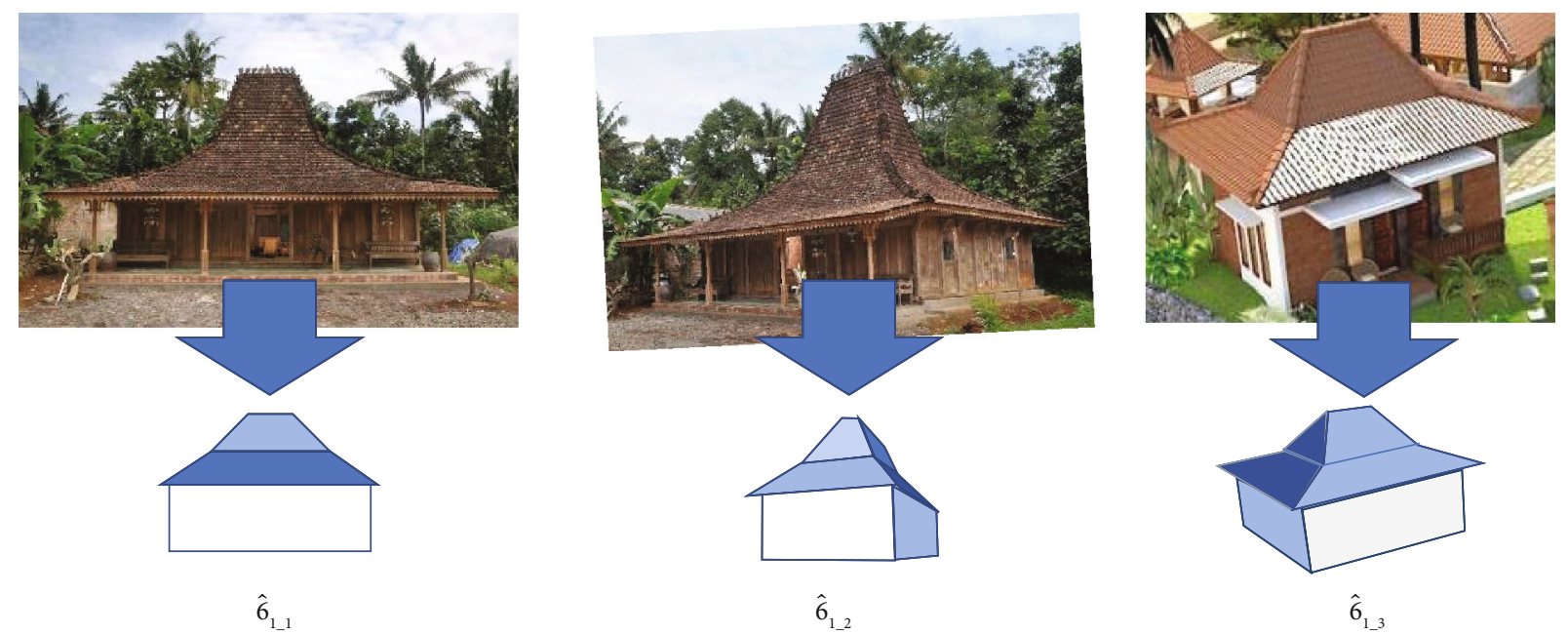

Figure 54: Building number $\widehat{\sigma}_{\alpha_{-} \beta}$.

of these traditional houses are similar from three different perspectives Figure 57. Building number $\widehat{7}_{1_{-} 1} \approx \widehat{7}_{1_{-} 2} \approx \widehat{7}_{1_{-} 3}$. Therefore, this building was assigned one building number $\left(\widehat{7}_{1-1}\right)$.

7.9.1. Projective Coordinate. The concept of projective coordinates must be introduced to identify the model of a traditional house. This concept was applied to categorize other traditional houses from Indonesia and other countries.

Definition 5. $(a, b, c)$ denotes the projective coordinate of a house diagram, where $a, b$, and $c$ are building numbers from one vanishing point, two vanishing points, and three vanishing points, respectively.

Note: if $A$ and $B$ are simple houses, $A$ and $B$ have the same projective coordinates if they are projective congruent.
Table 1 shows the codification based on building numbers and projective coordinates to categorizes traditional houses. We further categorized traditional houses from Indonesia and other countries, obtained from online sources and photos using these codification systems.

7.10. Some Examples from Other Countries. Building numbers and projective coordinates are concepts that can be used to categorize traditional buildings. Pictures of traditional houses from other countries were used to demonstrate the application of this concept.

Figure 58 presents two traditional buildings from Malaysia and New Zealand that were analyzed using building numbers and projective coordinates. The building numbers of these traditional buildings were $\widehat{4}_{1_{-1}}$ and $\widehat{4}_{1 \_2}$, respectively. Pictures of these buildings with three vanishing points were not available. However, we deduced that the building number 

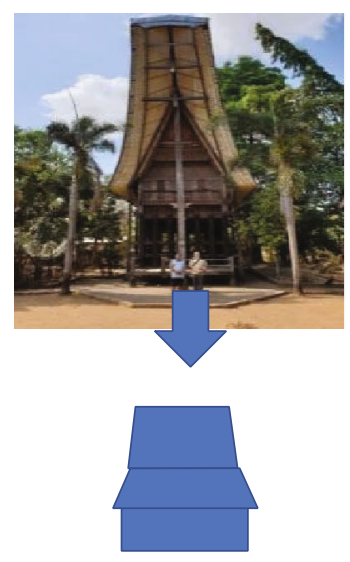

$\hat{6}_{1 \_1}$
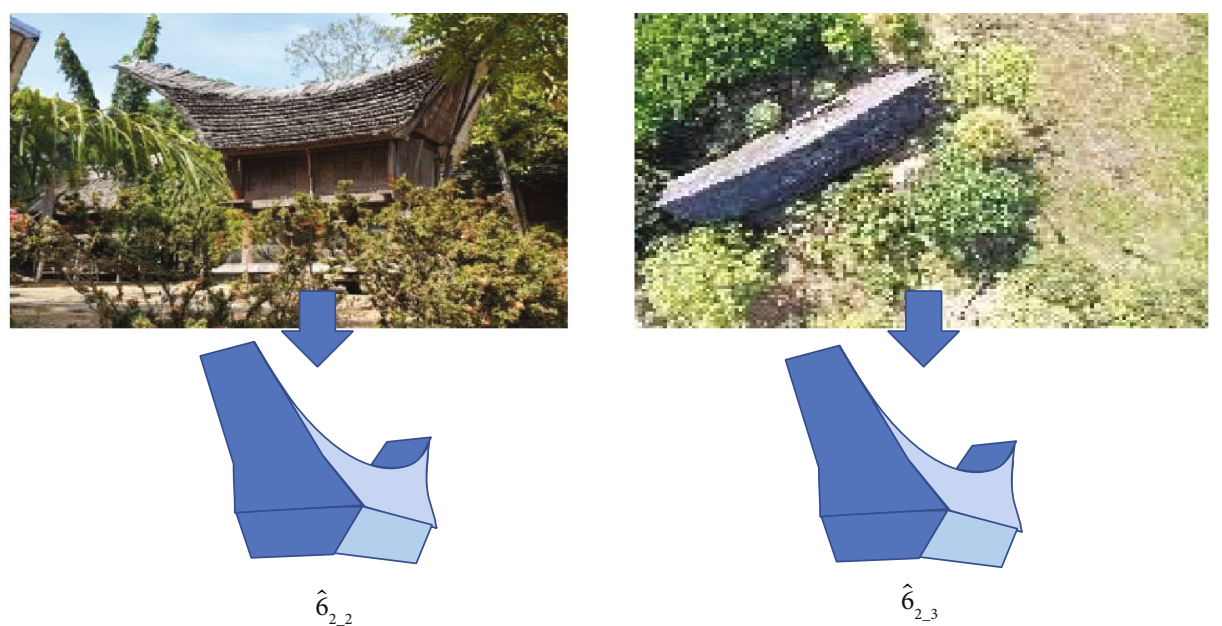

FIGURE 55: Building number $\widehat{6}_{\alpha \_\beta}$.
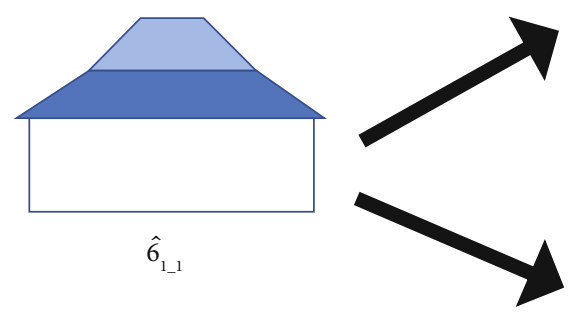

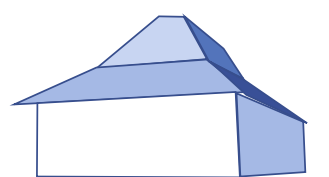

$\hat{6}_{1 \_2}$

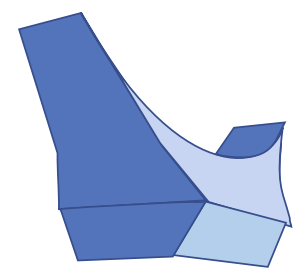

$\hat{6}_{2 \_}$
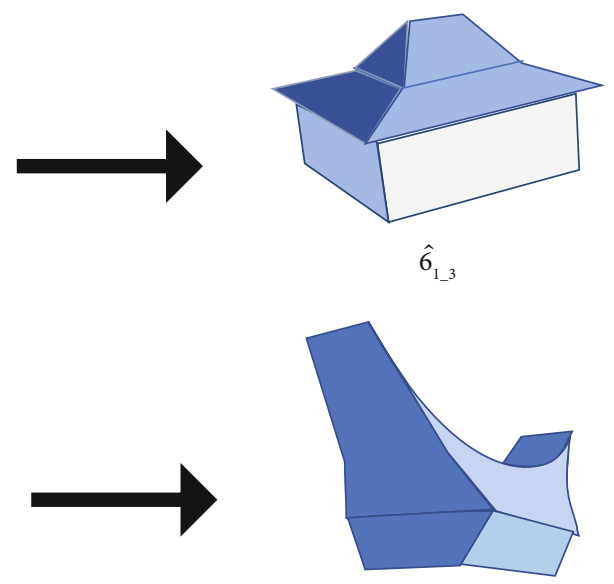

$\hat{6}_{2,3}$

Figure 56: The construction of building number $\widehat{\sigma}_{\alpha \_\beta}$.

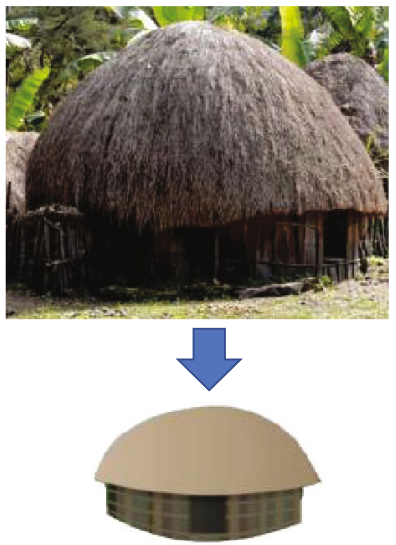

(a)

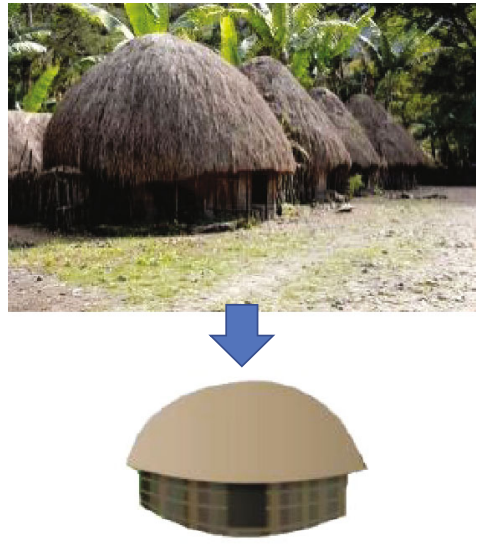

(b)

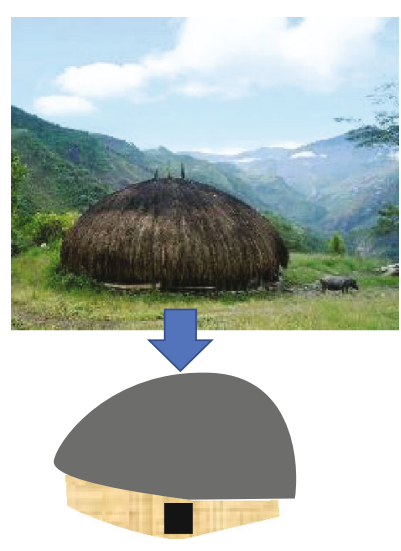

(c)

Figure 57: Hanoi House, example of Building Number $\widehat{7}_{\alpha_{-} \beta}$. 
TABLE 1: Summary of simple houses' projective coordinates.

The type of simple house.

Simple house I (cubic simple house)

Simple house II (triangular simple house)

Simple house III

Simple house IV

Simple house V

Simple house V

Simple house VII (paraboloid simple house)
One vanishing point Two vanishing points Three vanishing points Projective coordinates
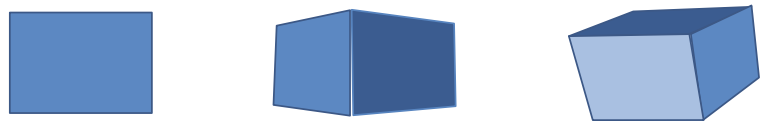

$\left(\widehat{1}_{1_{1}}, \widehat{1}_{1_{2}}, \widehat{1}_{1_{3}}\right)$
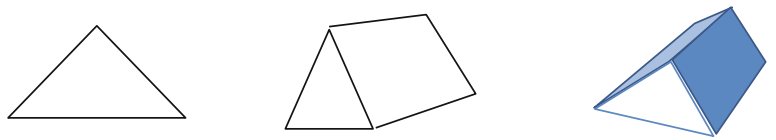

$\left(\widehat{2}_{1_{1}}, \widehat{2}_{1_{2}}, \widehat{2}_{1_{3}}\right)$
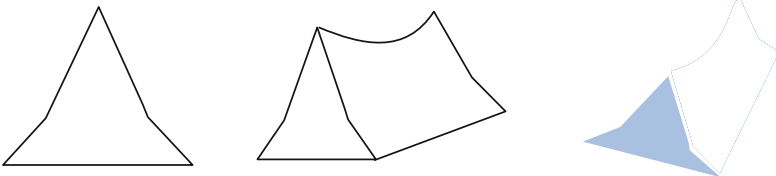

$\left(\widehat{3}_{1_{1}}, \widehat{3}_{1_{2}}, \widehat{3}_{1_{3}}\right)$
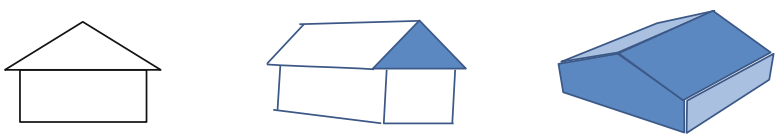

$\left(\widehat{4}_{1_{1}}, \widehat{4}_{1_{2}}, \widehat{4}_{1_{3}}\right)$
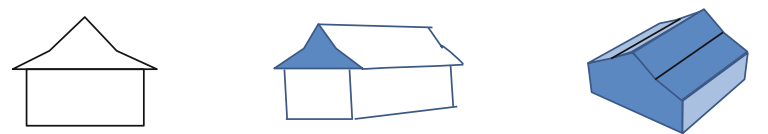

$\left(\widehat{5}_{1_{1}}, \widehat{5}_{1_{2}}, \widehat{5}_{1_{3}}\right)$
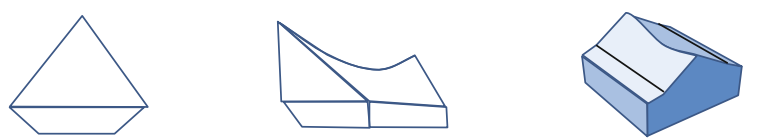

$\left(\widehat{5}_{1_{1}}, \widehat{5}_{2_{2}}, \widehat{5}_{2_{3}}\right)$
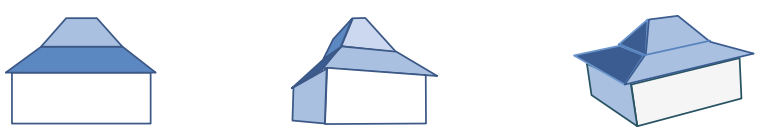

$\left(\widehat{\sigma}_{1_{1}}, \widehat{\sigma}_{1_{2}}, \widehat{\sigma}_{1_{3}}\right)$
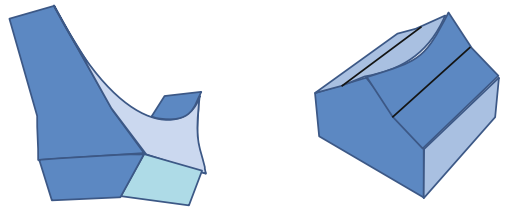

$\left(\widehat{\sigma}_{1_{1}}, \widehat{\sigma}_{2_{2}}, \widehat{\sigma}_{2_{3}}\right)$
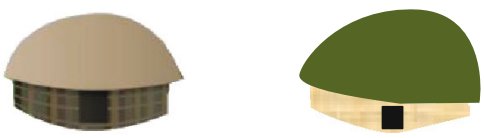

$\left(\widehat{7}_{1_{1}}, \widehat{7}_{1_{1}}, \widehat{7}_{1_{1}}\right)$ was $\widehat{4}_{1 \_3}$ with three vanishing points based on pictures that showed parts of the buildings. Therefore, the projective coordinates of the stilt house and Maori Reed House were $\left(\widehat{4}_{1 \_1}\right.$ $\left.\widehat{4}_{1 \_2}, \widehat{4}_{1 \_3}\right)$, and the vernacular architecture was categorized as simple house IV.

Figure 59 displays vernacular architecture from the Kysuce region in Slovakia. This log cabin was revealed to have projective coordinates $\left.\widehat{(5}_{1 \_1}, \widehat{5}_{1 \_2}, \widehat{5}_{1 \_3}\right)$. This traditional house was thus categorized as simple house $\mathrm{V}$.

Another notable traditional dwelling is the Apache house. This traditional house was recorded by Curtis (1868-1952) in 1903. The Apache dwelling pictured was in the southwest of North America (Figure 60).

The projective coordinates of the traditional building are $\widehat{7}_{1 \_1}, \widehat{7}_{1 \_1}$, and $\widehat{7}_{1 \_1}$, indicating that the Apache wickiup is an example of simple house VII.
7.11. Proposed Simple House Theory for Teaching Mathematics. The theory of building numbers and projective buildings will benefit students for five reasons. First, students can easily recognize the building types because the house diagrams are presented in simple geometric forms. Second, the categorization of every building can encourage students to identify the similarities between buildings around the world. Third, the house diagrams will encourage students to identify philosophies or similar principles embedded in their traditional buildings. Fourth, the introduction of building numbers and projective coordinates will teach students about simple models and the application of projective geometry and affine geometry in a straightforward manner. Fifth, learning building numbers and projective coordinates help students develop abstract thinking and allow them to perceive houses as mathematical symbols. 


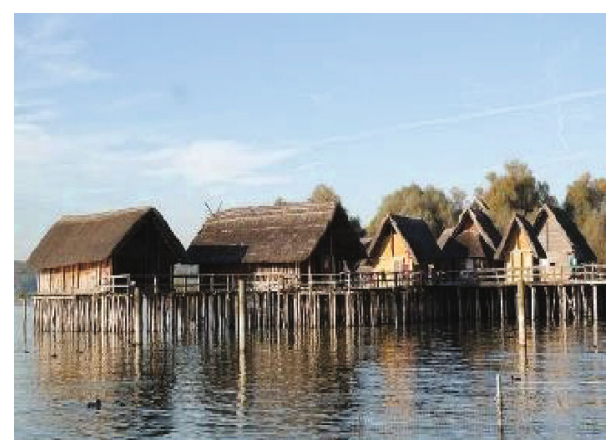

(a)

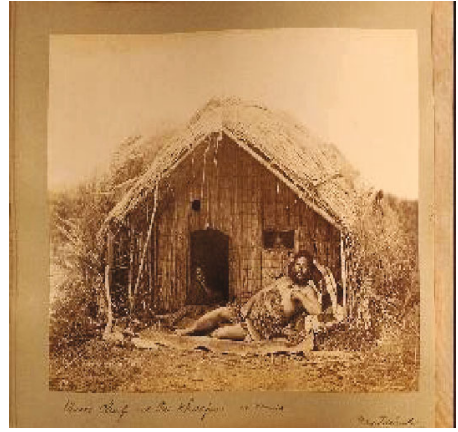

(b)

Figure 58: (a) Stilt houses: Asia; (b) Maori Reed House, New Zealand 1891 [35].

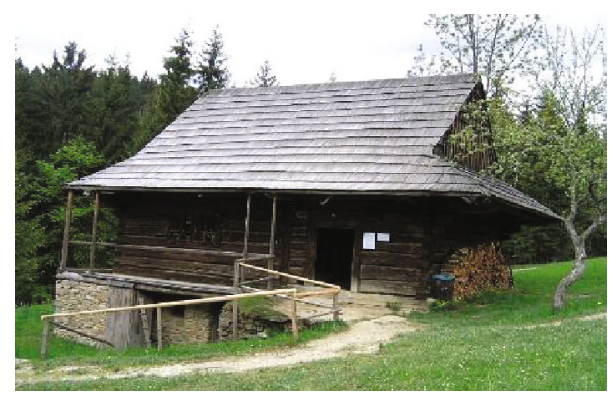

Figure 59: A log cabin in Slovakia [36].

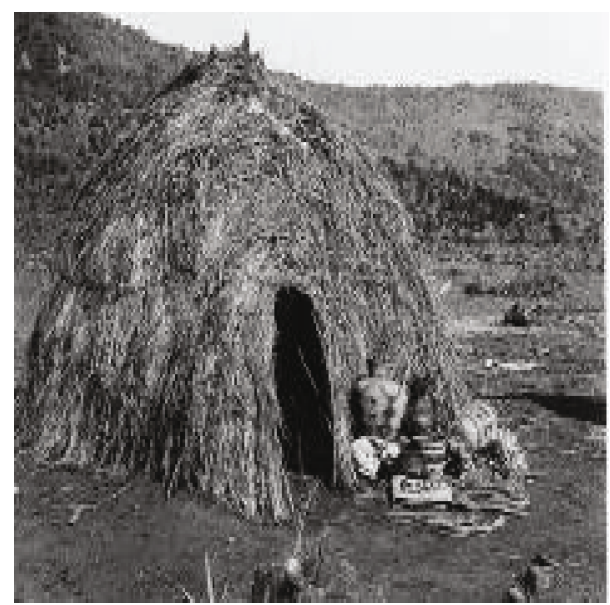

Figure 60: Apache wickiup [37].

We must consider including this simple house theory as a contextual problem for teaching and learning mathematics for several reasons. First, not all students have basic knowledge regarding geometric projection. Therefore, introducing projective geometry concepts and simple house theory is essential. Second, because this house theory is general and simple and the purpose is to categorize traditional houses, mathematics teachers should allow students to learn by observing traditional houses and making connections between their observations and related theory.

From an ethnomathematical perspective, the context of the teaching and learning process should be designed by embedding the culture, history, and philosophy underlying the traditional house design. This form of teaching would stimulate student awareness of the mathematical ability of tribes in solving their problems and the similarity between traditional houses in various countries. The learning environment would create a positive learning experience and meaningful learning [38].

Teachers or lecturers can provide explanations to students regarding projective geometry and simple house theory. To understand related problems, students could identify the projective coordinate of various traditional houses and use figures to determine the projective coordinates to identify traditional house types.

Students could also use their house as an example. Learning about traditional customs will make the teaching and learning process more engaging and benefit the students. Students' abilities, especially in geometry, will improve, which will increase their awareness regarding their culture and heritage. A detailed application of simple houses in the teaching and learning processes will be established in future research, and the application of this theory from an ethnomathematics perspective will be investigated.

\section{Conclusion}

In this study, 7 simple house types, 25 building numbers, and 9 projective coordinate categories were developed. The simple house categories were based on the basic form of each simple house presented with one vanishing point. The simple houses were categorized as simple house I (cubic), simple house II (triangular), simple house III, simple house IV, simple house V, simple house VI, and simple house VII (paraboloid). Examples of simple houses I and VI are categorized as stilt traditional houses. On the other hand, the examples of simple houses II, III, and IV are nonstilt traditional houses. Only simple house $\mathrm{V}$ has examples in both stilt house and nonstilt house. Building numbers were formulated as follows: $\widehat{1}_{1 \_1}, \widehat{1}_{1 \_2}, \widehat{1}_{1 \_3}, \widehat{2}_{1 \_1}, \widehat{2}_{1 \_2}, \widehat{2}_{1 \_3}, \widehat{3}_{1-1}, \widehat{3}_{1 \_2}, \widehat{3}_{1 \_3}, \widehat{4}_{1 \_1}, \widehat{4}_{1 \_2}$, $\widehat{4}_{1 \_3}, \widehat{5}_{1 \_1}, \widehat{5}_{1 \_2}, \widehat{5}_{1 \_3}, \widehat{5}_{2 \_2}, \widehat{5}_{2 \_3}, \widehat{\sigma}_{1 \_1}, \widehat{\sigma}_{1 \_2}, \widehat{\sigma}_{1 \_3}, \widehat{\sigma}_{2 \_2}, \widehat{\sigma}_{2 \_3}$, and $\widehat{7}_{1-1}$. The building numbers are components of the projective coordinates, which consist of the projective transformation in one vanishing point, two vanishing points, and three vanishing points. Projective coordinates were formulated for every simple house type. Simple houses I, II, III, 
IV, and V have projective coordinates $\left(\widehat{1}_{1_{1}}, \widehat{1}_{1_{2}}, \widehat{1}_{1_{3}}\right),\left(\widehat{2}_{1_{1}}\right.$, $\left.\widehat{2}_{1_{2}}, \widehat{2}_{1_{3}}\right),\left(\widehat{3}_{1_{1}}, \widehat{3}_{1_{2}}, \widehat{3}_{1_{3}}\right),\left(\widehat{4}_{1_{1}}, \widehat{4}_{1_{2}}, \widehat{4}_{1_{3}}\right),\left(\widehat{5}_{1_{1}}, \widehat{5}_{1_{2}}, \widehat{5}_{1_{3}}\right)$, and $\left(\widehat{5}_{1_{1}}\right.$, $\widehat{5}_{2_{2}}, \widehat{5}_{2_{3}}$ ), respectively. Similar to simple house V, which has two projective coordinates, simple house VI also has the coordinates $\left(\widehat{\sigma}_{1_{1}}, \widehat{\sigma}_{1_{2}}, \widehat{\sigma}_{1_{3}}\right)$ and $\left(\hat{\sigma}_{1_{1}}, \widehat{\sigma}_{2_{2}}, \widehat{\sigma}_{2_{3}}\right)$. Finally, simple house VII has a unique set of coordinates $\left(\widehat{7}_{1_{1}}, \widehat{7}_{1_{1}}, \widehat{7}_{1_{1}}\right)$.

\section{Data Availability}

All data generated or analyzed during this study are included in this published article

\section{Conflicts of Interest}

The authors declare that they have no conflict of interest.

\section{Acknowledgments}

This article was partially supported by the Ministry of Science and Technology, Taiwan, through grant MOST 1092511-H-029-002.

\section{References}

[1] A. Holme, Geometry: Our Cultural Heritage, Springer, Berlin, 2010.

[2] J. Soustelle, The Daily Life of the Aztecs: On the Eve of the Spanish Conquest, Macmillan, New York, 1962.

[3] J. P. Farrell, The Giza Death Star Deployed: The Physics and Engineering of the Great Pyramid, Adventures Unlimited Pr, Oklahoma, 2003.

[4] A. Imhausen, Mathematics in Ancient Egypt: A Contextual History, Princeton University Press, New York, USA, 2016.

[5] Rhind, "Teh Rhind Mathematical Papyrus," 2011, May 2019, https://www.britishmuseum.org/research/collection_online/ collection_object_details/collection_image_gallery .aspx?assetId=366139001\&objectId=110036\&partId=1.

[6] C. Bartlett, "The design of the Great Pyramid of Khufu," Nexus Network Journal, vol. 16, no. 2, pp. 299-311, 2014.

[7] S. Groniewicz, "Gasshō-zukuri house in the UNESCO World Heritage village of Shirakawa-go in autumn, Gifu, Japan," Alamy Stock Photo, 2014, July 2019, https://www.alamy .com/stock-photo-gassh-zukuri-house-in-the-unesco-worldheritage-village-of-shirakawa-80096822.html.

[8] F. V. D. J. van Hoof and F. van Dijken, "The historical turf farms of Iceland: architecture, building technology and the indoor environment," Building and Environment, vol. 43, no. 6, pp. 1023-1030, 2008.

[9] Zjctming, "A courtyard with a depth of garden, taken in Siheyuan hometown," 2008, July 2021, https://zh.wikipedia .org/wiki/\%E5\%9B\%9B\%E5\%90\%88\%E9\%99\%A2\#/media/ File:Xsgl2.jpg.

[10] W.-H. Chen and Ja'faruddin, "Mathematics used in the Indonesian's traditional buildings," Universal Journal of Mathematics and Mathematical Sciences, vol. 12, no. 1, pp. 1-14, 2019.

[11] M. A. McIntosh, "History of the longhouse," 2017, July 2021, https://brewminate.com/history-of-the-longhouse/.
[12] mkuebler5, "Early settlers cottage Australia with beautiful views," mkuebler5, 2017, July 2021, https://www.youtube .com/watch?v=pjq-FAQ1eGg.

[13] J. Hays, "Japanese architecture: wood earthquakes tea rooms and traditional homes," 2009, May 2019, http:// factsanddetails.com/japan/cat20/sub129/item687.html.

[14] D. A. Brannan, M. F. Esplen, and J. J. Gr, Geometry, Cambridge University Press, Cambridge, 2012.

[15] U. D'Ambrosio, "An Overview of the History of Ethnomathematics," in Current and Future Perspectives of Ethnomathematics as a Program, pp. 5-10, Springer Nature, Hamburg, Germany, 2016.

[16] M. Rosa and L. Shirley, "Introduction," in Current and Future Perspectives of Ethnomathematics as a Program, pp. 1-3, Springer Nature, Hamburg, 2016.

[17] A. Y. A. H. M. M. S. Syarif, "Sulapa eppa as the basic or fundamental philosophy of traditional architecture Buginese," in International Conference on Architectural Education in Asia (eduARCHsia 2017), Yogyakarta, Indonesia, 2018.

[18] W. N. Yanuarto, "Notice of retraction ethnic vs math: the secret inside Borobudur Temple, Indonesia," Journal of Education and Learning (EduLearn), vol. 11, no. 1, pp. 75-82, 2017.

[19] W. Zhang and Q. Zhang, "Ethnomathematics and its integration within the mathematics curriculum," Journal of Mathematics Education, vol. 3, no. 1, pp. 151-157, 2010, http:// educationforatoz.org/images/_12_Weizhong_Zhang_and_ Qinqiong_Zhang.pdf.

[20] U. D'Ambrosio, "Ethnomathematics and its place in the history and pedagogy of mathematics," For the Learning of Mathematics, vol. 5, pp. 44-48, 1985.

[21] Z. Sagdic, Mathematical Connection in Art, Music and Science, Bridges London, London, 2006.

[22] I. G. P. Suharta, I. G. P. Sudiarta, and I. W. P. Astawa, "Ethnomathematics of Balinese traditional houses," International Research Journal of Engineering, IT \& Scientific Research, vol. 3, no. 4, pp. 42-50, 2017.

[23] K. Teng, "The Culture SG," 2016, 2019, https://theculture.sg/ 2016/11/assess-the-view-that-traditional-buildings-have-nofuture-in-your-society/.

[24] S. Yudohusodo, Rumah untuk Seluruh Rakyat, INKOPPOL Unit Percetakan Bzzharakerta, Jakarta Indonesia, 2007.

[25] M. A. Penna and R. R. Patterson, Projective Geometry and Its Application to Computer Graphics, Kai Fa Book Company, Taipei, 1986.

[26] L. Wicaksono, “Mengunjungi Masjid Ka’bah Subang Luar dalam sungguh indah,” traveling yuk, 2017, July 2021, https://travelingyuk.com/masjid-kakbah-subang/63068.

[27] wakhyuningngarsih, "Uma Lengge, rumah tinggal yang beralih fungsi menjadi lumbung padi," Dokumen Pencatatan WBTB BPNB Bali, 2017, July 2021, Available: https:// kebudayaan.kemdikbud.go.id/bpnbbali/uma-lengge-rumahtinggal-yang-beralih-fungsi-menjadi-lumbung-padi/.

[28] C. Angelita, R. F. Manurung, N. M. Y. Sugiantari, A. S. Putri Khinari, and R. A. Bawono, "Pengaruh Bangunan Uma Lengge terhadap Kehidupan Sosial dan Budaya MASYARAKAT Desa Maria Kecamatan Wawo Kabupaten Bima," Forum Arkeologi, vol. 32, no. 1, pp. 13-24, 2019.

[29] A. Sulistyawati, "Letusan toba pengaruhi arsitektur rumah adat Batak Toba," 2019, July 2021, https://interaktif.kompas .id/baca/rumah-adat-batak-toba/. 
[30] N. Napitupulu, E. Aritonang, and S. Silitonga, "The study about the comparation between Batak Toba traditional house in Huta Raja Samosir and Lumban Binanga Toba Samosir," IOP Conference Series Earth and Environmental Science, vol. 452, p. 012052, 2020.

[31] P. P. Yunus, "Makna simbol bentuk dan seni hias pada Rumah Bugis Sulawesi Selatan," Panggung, vol. 22, no. 3, pp. 225-350, 2016.

[32] D. K. D. Informatika, "Rumah adat Sao Mario," 2017, September 2019, https://soppengkab.go.id/rumah-adat-sao-mario/.

[33] D. Sundari, "Filosofi dan sejarah rumah Joglo," 2018, June 2019, https://www.kompasiana.com/dewisundari/ 5968247f1a208004da5ce612/filosofi-dan-sejarah-rumahjoglo.

[34] H. Nooy-Palm, The Sa'dan-Toraja: A Study of their Social Life and Religion, Springer Science+Business Media Dordrecht, Leiden Netherland, 1979.

[35] N. P. Service, “Maori Reed House New Zealand 1891," Longfellow House-Washington's Headquarters National Historic Site, 1891, July 2021, https://commons.wikimedia.org/wiki/ File:Maori_Reed_House,_New_Zealand,_1891_(1946e3cd7fa0-491f-9fb6-2fdbc117ad76).JPG.

[36] Juloml, "Múzeum kysuckej dediny,” 2006, https://en.wikipedia .org/wiki/File:M\%C3\%BAzeum_kysuckej_dediny-1.jpg.

[37] E. Curtis, “Apache wickiup, Edward Curtis, 1903.jpg," 1903, https://en.wikipedia.org/wiki/File:Apache_Wickiup,_ Edward_Curtis,_1903.jpg.

[38] Ja'faruddin, H. Upu, C. Wen-Haw, and D. C.-E. Teng, "The comparison between two hypnoteaching models in mathematics teaching and learning," International Electronic Journal of Mathematics Education, vol. 15, no. 3, p. em0607, 2020. 